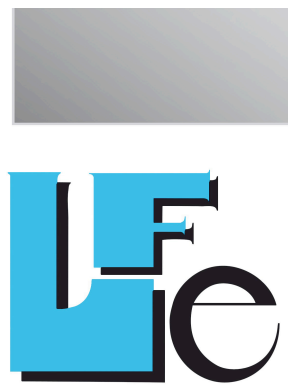

Revista de Lenguas para Fines Específicos

\section{Revista de lenguas para fines específicos}

\section{elSSN: $2340-8561$}

Journal information, indexing and abstracting details, archives, and instructions for submissions: https://ojsspdc.ulpgc.es/ojs/index.php/LFE/index

\section{Grammatical means of textual cohesion in appellate court decisions}

Zuzana Nadova

Department of British and American Studies, Faculty of Arts,

P.J.Safarik University in Kosice (Slovakia).

Article first published online: 25 November 2015.

Article published online with DOI added: 5 April 2016. 
DOI: http://dx.doi.org/10.20420/rlfe.2015.0010

\title{
Grammatical means of textual cohesion in appellate court decisions
}

\author{
Zuzana Nadova ${ }^{1}$ \\ P. J. Safarik University in Kosice, Slovakia
}

\begin{abstract}
The submitted paper deals with analysis of grammatical means of textual cohesion in English in a specific genre of legal register, i.e. in appellate court decisions. The theoretical framework of analysis is the theory of textual cohesion introduced by Halliday and Hasan in their work Cohesion in English (1976), which considers only intersentence cohesive ties to be textually cohesive and which distinguishes four categories of grammatical cohesion: reference, substitution, ellipsis and conjunction. In the analysed texts, all the instances of these four categories of grammatical cohesion are identified and statistically evaluated. The aim of the analysis is twofold. The first goal of research is to find out what kinds of cohesive devices appear with the highest frequency. Another focus of analysis is to find out whether the grammatical means of textual cohesion under analysis contribute to the stylistic qualities of the analysed texts and make them unambiguous and clear enough for interpretation. The findings of the analysis as well as their subsequent comparison with other registers indicate that the most frequent grammatical means of textual cohesion, namely demonstrative reference and additive conjunction, significantly contribute to precision, formality and logical organization of the analysed genre of legal English.
\end{abstract}

Keywords: textual cohesion, reference, substitution, ellipsis, legal English

1 Corresponding author - Department of British and American Studies, Faculty of Arts, P.J.Safarik University in Kosice (Slovakia).

Email: zuzana.nadova@hotmail.com 


\begin{abstract}
Abstrakt
Predložená štúdia sa zaoberá analýzou gramatických prostriedkov textovej kohézie $v$ angličtine $v$ špecifickom žánri právnych textov, v rozhodnutiach odvolacieho súdu. Teoretickým východiskom analýzy je teória textovej kohézie, ktorú vypracovali Halliday a Hasan vo svojom diele Cohesion in English (1976). Autori považujú za zdroj textovej kohézie iba tie prostriedky, ktoré vytvárajú kohézne väzby medzi vetami a rozlišujú štyry typy textovej kohézie: odkazovanie, substitúciu, elipsu a gramatické spojenie. Všetky príklady výskytu týchto gramatických prostriedkov textovej kohézie $v$ analyzovaných textoch sú zrátané a štatisticky vyhodnotené. Cielom výskumu je zistit to, či sú analyzované texty bohaté na výskyt gramatických kohéznych väzieb ako aj to, ktoré gramatické prostriedky textovej kohézie sa v textoch vyskytujú najčastejšie. Ďalším ciel'om analýzy je zistit́, či inventár gramatických prostriedkov textovej kohézie $v$ daných textoch prispieva $\mathrm{k}$ ich štylistickým vlastnostiam, typickým pre právne texty a zvyšuje ich zrozumitel'nost' a významovú jednoznačnost'. Na základe výsledkov analýzy ako aj na základe porovnania týchto výsledkov analýzy s výskytom gramatických prostriedkov textovej kohézie v textoch iných registrov je možné označit ako najčastejšie prostriedky právnej angličtiny odkazovanie a gramatické spojenie, ktoré významne prispievajú k presnosti, logickej organizácii a formálnemu štýlu skúmaných textov.
\end{abstract}

Klúčové slová: textová lingvistika, textová kohézia, odkazovanie, substitúcia, elipsa, gramatické spojenie, právnická angličtina

\title{
1. Introduction
}

Many linguists assert that textual cohesion, realized by grammatical and lexical means, is a property which "distinguishes texts from non-texts" (Halliday and Hasan, 1976, p. 7) and which creates continuity and establishes semantic relations within the text (Dolník, 1979; Dušková, 1984; Bajzíková, 1995). Lexicogrammatical means of textual cohesion thus play a crucial role in correct interpretation of the text.

The present paper deals with analysis of grammatical means of textual cohesion in a corpus of appellate court decisions on the basis of the theory of textual cohesion, elaborated by Halliday and Hasan within the framework of Systemic Functional Linguistics (hereafter abbreviated as SFL). ${ }^{2}$ More specifically, the purpose of this paper is to summarize the results of analysis of frequency of occurence of

In the Hallidayan SFL approach, which distinguishes three functional components of the semantic system of language (ideational, interpersonal and textual), cohesion is studied within the textual component. The textual component is constituted by structural and non-structural elements and cohesion is the representation of non-structural part of the textual component of language (Halliday and Hasan, 1976, p. 29). This means that in Halliday's SFL approach, the study of cohesion involves only cohesive devices that operate above clause level. 
grammatical cohesive devices as classified by Halliday and Hasan: reference, substitution, ellipsis and conjunction in the selected legal genre. The obtained results were subsequently compared with the frequency and types of grammatical cohesive devices employed in other registers ${ }^{32}$ (fiction and newspaper articles) on the basis of data arrived at by linguists, analyzing textual cohesion within SFL framework.

In the last few decades, legal English has become the focus of linguistic research within various theoretical frameworks and from many different perspectives. Many linguists focused their attention on stylistic characteristics of this register, e.g. Mellinkoff (1963), Danet (1985), Bhatia and Swales (1983), Trosborg (2000), Engberg and Heller (2008), and many others. The most frequently enumerated stylistic qualities of legal texts usually include precision, unambiguity, intelligibility, logical organization of content, objectivity and formality (Tomášek, 1998; Mellinkoff, 1963; Danet, 1985). The present analysis aims to prove that these stylistic qualities are also contributed to by correct employment of grammatical means of textual cohesion in the analyzed texts.

\section{Objectives of research}

The aim of the analysis to prove that the analysed legal genre is rich in intersentence cohesive items (more than 1 cohesive item per sentence), all of which should be unambiguous and clear for interpretation, thus contributing to precision, unambiguity and intelligibility of the genre. Halliday and Hasan (1976) assert that "cohesive items create continuity of discourse and ongoing continuity of discourse is a primary factor for its intelligibility" (p. 349). In Halliday and Hasan 's theory, cohesion is thus closely tied with coherence of the text. ${ }^{4}$

According to Halliday and Hasan (1976), cohesion is objectively verifiable through text analysis. In the analysis of grammatical cohesive devices, the most important criteria taken into consideration by the authors are the following:

3 Although many linguists define register as level of formality (e.g. Bolinger, 1975), in this paper the term register is used in the same way as it is understood by Halliday and Hasan, i.e. as a set of texts with specific properties used in specific circumstances: "The register is the set of meanings, the configuration of semantic patterns, that are typically drawn upon under the specified conditions, along with the words and structures that are used in the realization of these meanings" (Halliday and Hasan, 1976, p. 23).

$4 \quad$ Halliday and Hasan define cohesion as explicit linguistic expression of semantic relations above the clause level while coherence is defined by these authors as mental creation of meaning relations during text processing. Of course, both cohesion and coherence contribute to the intelligibility of the text. 
1. distance between the presupposed and presupposing cohesive item (they distinguish between immediate, mediated and remote ties)

2. types of semantic relations constituted by grammatical means of cohesion (reference, substitution, ellipsis and conjunction).

The presented analysis of grammatical cohesive devices covers both of these dimensions of cohesion: distance and semantic relations created by cohesive ties.

According to Halliday and Hasan`s findings (1976), formal types of discourse have less complex patterns of cohesion than informal types of discourse, i.e. they contain a smaller proportion of remote ties (i.e. cohesive ties between items in sentences which are separated by an intervening sentence not participating in the cohesive relation) and mediated ties (i.e. cohesive ties between items in sentences separated by an intermediate sentence containing an item which is both presupposed and presupposing). Therefore it is expected that most cohesive ties found in the analysed texts (more than 50\%) will be instances of immediate ties (i.e. cohesive items occurring in adjacent sentences). This expectation bears on the following fact described by Halliday and Hasan (1976): remote ties make the reader search for the presupposed item in the surrounding text and thus require more effort from the reader in constructing the meaning of the text (p. 349). Logically, if the distance between cohesive items is too long, the reader can connect the presupposing item with the wrong presupposed item, which leads to incorrect interpretation of the intended meaning. In legal texts, this quality could have negative and far-reaching consequences.

A more specific hypothesis, concerning the expected types of grammatical referential ties in terms of semantic relations they create in the text, holds that the most frequent cohesive ties will be instances of reference and conjunction. More specifically, it is expected that the most numerous types of cohesive ties will be demonstrative referential ties because they are "the most precise and unambiguous types of cohesive ties" (Halliday and Hasan, 1976, p. 143), i.e. they contribute to qualities which are highly desired in legal language. Among conjunctive cohesive ties, it is expected that the most frequent ties will be instances of causal conjunction, which is a formal expression of logical organization of the text. Therefore in the analysed legal genre, which gives the details of the decision of the appellate commission, causal links between sentences are expected to be the most numerous. 


\section{Previous treatments of textual cohesion and theoretical framework of research}

Before and even after Halliday and Hasan's new theory of textual cohesion, linguists differed considerably in their opinions on which lexicogrammatical devices should be considered textually cohesive. Halliday and Hasan exclude from their theory of textual cohesion all structural elements, i.e. elements at clausal level. That means that only elements establishing semantic relations between sentences are considered to be textually cohesive. Waldemar Gutwinski (1976) included in his study of textual cohesion some structural elements, e.g. conjunctions as paratactic and hypotactic connectors, while Halliday and Hasan consider only intersentence conjunction to be cohesive. Similarly, Eugene Winter's conception of textual cohesion (1975) included theme choice and parallelism, which are also classified as structural elements in Halliday and Hasan`s theory.

The main tenets of Haliday and Hasan's theory of textual cohesion are explained in their seminal work Cohesion in English (1976). The authors emphasize that cohesion is a semantic relation or a relation of meaning which is not structural, i.e. it is $a$ relation beyond sentence structure. Thus cohesion is understood as a semantic relation, realized through lexicogrammatical resources in the surface structure of the text and not as a mere presence of these devices. Studies of textual cohesion prior to Halliday and Hasan's work were aimed mainly at fiction, while more recently textual cohesion has also been studied in speech, e.g. by Sanna-Kaisa Tanskannen (2004) and Maria Teresa Taboada (2006).

In Halliday and Hasan 's theory of cohesion, the focus is on the meaning relations, "the semantic resources which are drawn on for the purpose of creating a text"( $p$. 10). The present analysis concentrates on meaning relations in the selected genre and on identification of cohesive items contributing to accuracy, intelligibility and other stylistic qualities, therefore it adopts Halliday and Hasan's SFL approach and classification of grammatical cohesive ties.

\section{Corpus and methodology of research}

The corpus under analysis consists of six appellate court decisions covering various topics of employment law in the USA. The main goal of research is to find out whether the model of textual cohesion developed by Halliday and Hasan, which takes into account only intersentence cohesion, can be applied to such a specific type of texts as legal texts and whether legal texts, which are often characterized as texts containing long and elaborate sentences with complex sentence structure are rich in intersentence cohesive devices. 
The analysed texts were chosen for a number of reasons. First, they are not extreme examples of legal writing with extremely long and complex sentences and a typical loose sentence structure and therefore they are very suitable for the analysis of intersentence cohesion. Further, the analysed texts are aimed at ordinary people and the clarity and intelligibility of the language used, including means of cohesion, is therefore of crucial importance. In addition, the conditions under which the appellate court decisions are written are also an important factor contributing to the suitability of these texts for analysis of the means of textual cohesion. They are not examples of strict formulaic legal genres and they are written by various authors and so the analysed appellate court decisions are expected to display variations in the use of lexical and grammatical elements. Consequently, it is expected that the inventory of means of textual cohesion will be rich and diverse.

The cohesive items under analysis were manually extracted from six appellate court decisions, which contain 8684 words in 22 pages of running text. A list of 265 cohesive ties extracted from the analysed texts is included at the end of analysis in the form of six tables (appendix 1, pp. 24-37). These tables include six important data for a closer identification of a particular cohesive tie: 1 . the number of sentence in which the cohesive item was found, 2 . the number of cohesive items in that particular sentence which relate that sentence cohesively to the surrounding text, 3 . the analysed cohesive item, 4. type of cohesion, 5. distance between the presupposing and the presupposed element and finally 6 . the presupposed item.

The obtained data were statistically, i.e. quantitatively evaluated and the results were qualitatively interpreted in relation to stylistic qualities of legal register.

The importance of manual extraction of data stems from the selected theoretical framework which considers textual cohesion to be a (i) a meaning relation between two items which are coreferential, and not a simple occurrence of one item in isolation and which considers only (ii) intersentence cohesive ties to be textually cohesive. The selection of cohesive ties under analysis can be briefly illustrated by the following example:

$$
\begin{aligned}
& \text { In addition, we note that an employer is not obligated to withhold } \\
& \text { discipline or termination of an employee who, because of a disability, } \\
& \text { violated a conduct rule that is job-related for the position in question } \\
& \text { and consistent with business necessity (text } 1, \text { Se } 44 \text { ). }
\end{aligned}
$$

The sentence in example (1) is cohesively linked to the surrounding text by means of three cohesive ties: the complex additive in addition establishes a conjunctive cohesive tie with the previous sentence, the personal pronoun we participates in a mediated cohesive chain including the pronoun we in sentence 43 and the 
presupposed item the Commission in sentence 42 and the definite article in the noun phrase the (position in question) creates a remote demonstrative referential cohesive tie with the presupposed item A PS 04 mail handler in sentence 5 . The detected cohesive ties in example (1) were tabulated as follows:

\begin{tabular}{l|l|l|l|l|l}
\hline Se. Nr. & $\begin{array}{l}\text { Nr. of } \\
\text { ties }\end{array}$ & $\begin{array}{l}\text { Cohesive } \\
\text { item }\end{array}$ & Type & $\begin{array}{l}\text { Distan } \\
\text { ce }\end{array}$ & Presupposed item \\
\hline 44 & 3 & in addition & $\begin{array}{l}\text { C, additive, complex, } \\
\text { emphatic, I }\end{array}$ & 0 & Se 43 \\
\cline { 2 - 6 } & $\begin{array}{l}\text { the (position } \\
\text { in question) }\end{array}$ & R, dem., def. art. & N. 39 & A PS - 04 mail handler \\
\hline & We & $\begin{array}{l}\text { R, pronominal, pers. } \\
\text { pronoun, plural }\end{array}$ & M. 2 & $\begin{array}{l}\rightarrow \text { we } \rightarrow \text { we } \rightarrow \text { the } \\
\text { Commission }\end{array}$ \\
\hline
\end{tabular}

Table 1. Cohesive devices in example (1)

A full list of symbols and abbreviations used in the analysis is provided after the appendix, and all the cohesive ties considered for the analysis are listed in the appendix.

\section{Analysis and findings}

The analysis revealed that the analysed appellate court decisions consist of passages which significantly differ in their cohesive patterns. They include "narrative" passages (called Issue Presented, Background, Analysis and Findings, Conclusion) in which the criminal cases in question are discussed and depicted and which show tight grammatical textual cohesion with a rich inventory of various types of intersentence cohesive items. Out of the analysed 265 cohesive ties, 163 ties were found in those parts of the texts which describe the criminal case in question or give details of the decision of the commission. The average number of ties per sentence in passages with tight textual cohesion is 1,79. These passages are connected with passages containing legal definitions (called Statement of Rights, Right to Request Counsel, Right to File a Civil Action, Certificate of Mailing) which exhibit loose cohesive pattern and low intersentence cohesion. The number of cohesive ties in these passages is 93 and the number of ties per sentence is 0,93. In the whole analysed corpus, the average number of ties per sentence is 1,52 , which is a sufficient proof supporting the hypothesis that the number of ties per sentence necessary to make it cohesively incorporated into the surrounding text is $\geq 1$.

The analysis of the distance between cohesive items revealed that the prevailing type of cohesive ties are immediate cohesive ties as anticipated, i.e. the most favourable type of ties in terms of correct interpretation of the cohesive relation, 
constituting 197 out of 265 instances. The number of ties that are both mediated and remote is 23, the number of mediated ties is 9 and the number of ties that are just remote is 66 . These data support the hypothesis that formal registers contain cohesive patterns which are less complex than those in informal registers. The distribution of the grammatical cohesive ties in the analysed texts is graphically illustrated in Graph 1, below.

\subsection{Reference}

As can be seen in Graph 1, reference turned out to be the most numerous type of grammatical cohesive device in the analysed texts, followed by conjunction, substitution and ellipsis.

Halliday and Hasan (1976) define reference as "the relation between an element of the text and something else by reference to which it is interpreted in the given instance "(p. 308). They use the term reference to denote textual reference, which they call endophoric reference. Endophoric reference may be either anaphoric, i.e. referring to preceding text, or cataphoric, i.e. referring to following text. The term exophoric reference is used in their theory for reference to the context of situation, i.e. situational reference. Therefore only endophoric reference is cohesive.

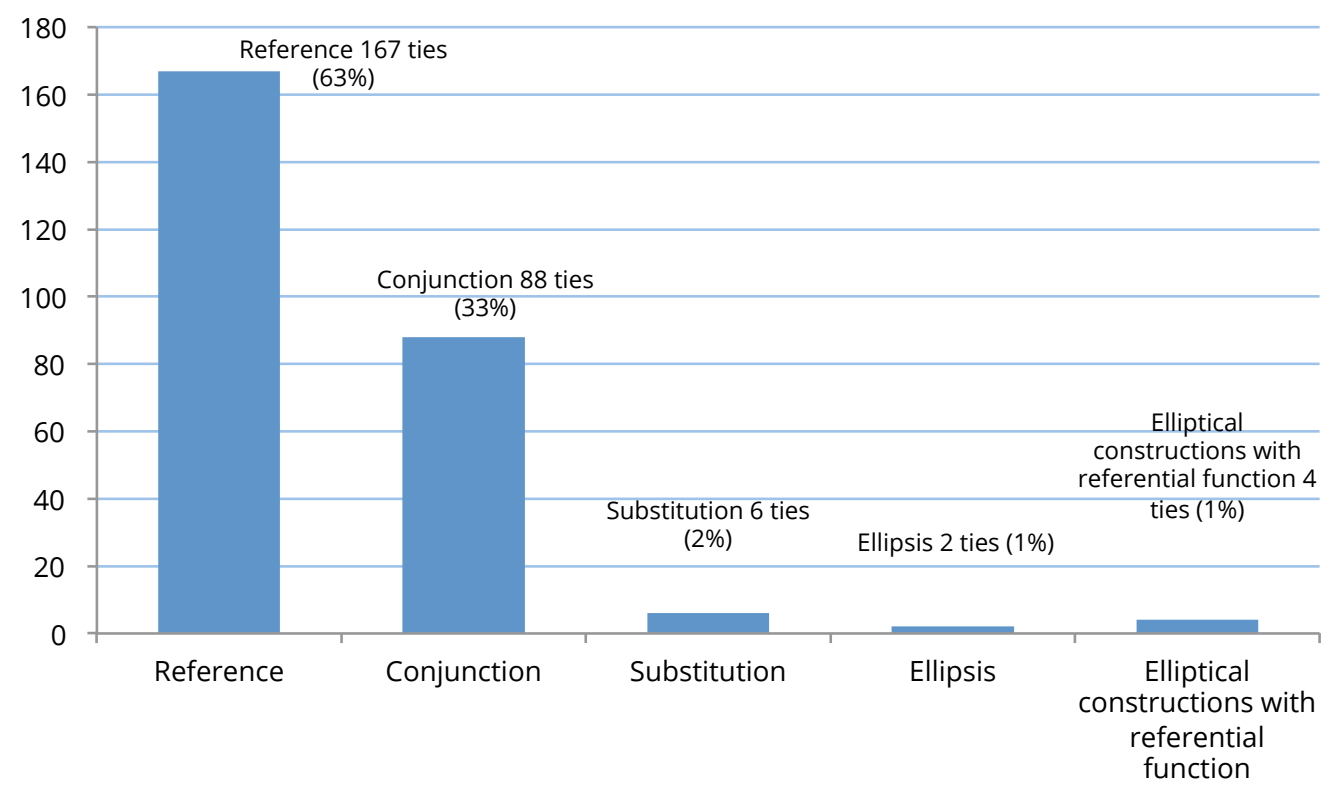

Graph 1. Distribution of grammatical cohesive ties in the corpus of Appellate Court Decisions 
Among referential cohesive ties, the highest frequency position is occupied by demonstrative referential ties, followed by personal and comparative referential ties:

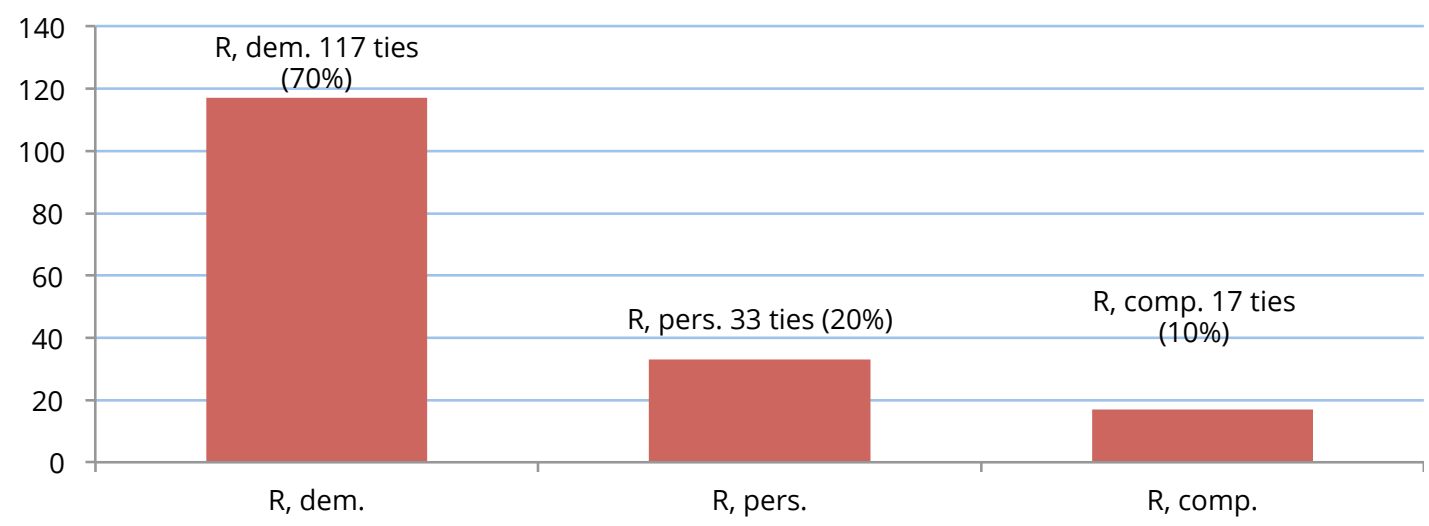

Graph 2. Distribution of referential cohesive ties in the corpus of Appellate Court Decisions

The demonstrative referential cohesive ties are formed by the definite article ( 84 ties), demonstrative pronouns this, that, these and those and by pronominal adverbs. In all the analysed instances, the two items forming a cohesive tie occurred in adjacent sentences and therefore they are the strongest and the most unambiguous cohesive ties. The use of the demonstrative pronouns this and that in legal English was studied by a number of linguists. The conclusion drawn by Kurzon is as follows:

The proximity opposition between this and that is neutralized in legal language. The demonstrative this is used exclusively as a deictic cohesive device pointing to the text at hand whereas the demonstrative that functions anaphorically or cataphorically in sequentially related sentences (Kurzon, 1983, p. 378).

This specialized usage of this and that was not proved in 100\% of the occurences of this and that in the corpus. Out of the 17 instances of demonstrative referential ties realized by the demonstrative pronoun this, 6 cases are instances of anaphoric ties:

In its February 28, 1993, FAD on this matter, the agency rejected the AJ's determination, and made a finding of no discrimination. Appellant appealed this determination to this Commission, and we issued a decision on May 30, 1997, which, in pertinent part, reversed the FAD and affirmed the AJ's finding of discrimination (Text 6, Se 8 - 9). 
While the demonstrative this in this determination builds an anaphoric referential link with the previous sentence, the demonstrative this in this Commission is an example of exophoric reference.

A specific group of referential items, which are considered to be typical of legal register by many authors (Mellinkoff, 1963; Maley, 1987; Danet, 1985), is the group of pronominal adverbs. In the analysed texts, pronominal adverbs have both exophoric and endophoric referential function.

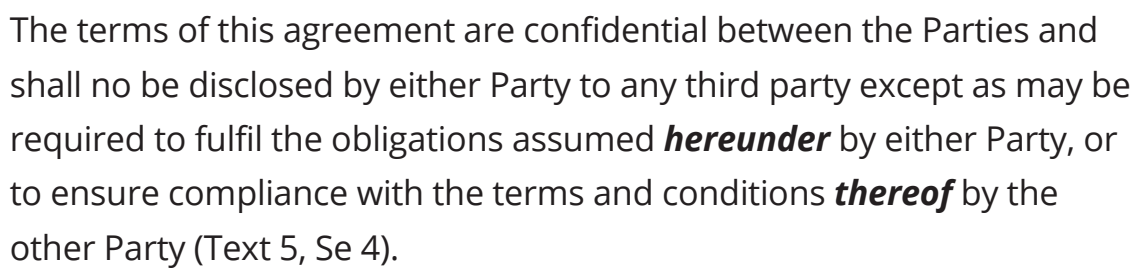

While the pronominal adverb hereunder refers to the agreement as a legal act (exophoric reference), the pronominal adverb thereof has its presupposed item in the same sentence and thus constitutes an anaphoric referential link: this agreement - thereof.

The numerous occurences of pronominal adverbs in the analysed texts signal their typicality of legal writing. Altogether, there are 20 instances of pronominal adverbs, out of which 14 items function as exophoric referential items and 6 items are endophoric, functioning as anaphoric referential items.

The use of pronominal reference in the analysed texts is very limited: most frequently, the items that could be referred to by pronominal referential ties (appellant, petitioner, commission, agency) are mentioned explicitely. The reason for such a low occurence of pronominal reference can be found in the requirement of precision in legal texts. Pronominal reference items could be connected with the wrong presupposed item and therefore it is of crucial importance to ensure unambiguous and precise reference in legal texts by means of reiteration of the same lexical item.

Several cases of pronominal reference as an intersentence cohesive device are realized by personal pronouns he ( 8 cohesive ties) and it (5 cohesive ties). The remaining cases of pronominal reference are realized by the personal pronouns they and we (18 cohesive ties). Pronominal reference realized by possessive pronouns was very rare: our ( 6 cohesive ties), her (1 cohesive tie) and his (1 cohesive tie).

In all these cases, pronominal reference was used in sentences only in those passages of the text, where there was only one possible referent and in all the cases, it was used in adjacent sentences containing either the referent or the pronominal 
reference item. There was never an intervening sentence which would interrupt the referential tie. All the cohesive ties, containing pronominal reference in the analysed texts are immediate ties and are unambiguous and clear for interpretation.

Comparative referential ties in the analysed corpus often span large passages of the texts, linking sentences which are remote from each other and are separated by a large number of intervening sentences (the average distance between sentences linked by comparative reference is 8.56 sentences). However, even if the average distance between items of comparative referential ties is greater than the distance between items building demonstrative referential ties, their linking power is increased by the semantic information which they convey. In all cases, items linked by comparative reference involve precise data, such as numbers, and so they are easier to trace in the text.

\subsection{Substitution}

Substitution is a relation at the lexicogrammatical level (while reference was defined as a relation at the semantic level), defined by Halliday and Hasan as "explicit ellipsis" (p. 317).

Substitution is a very rare intersentence cohesive device in the analysed texts. In the overall number of the analysed sentences, i.e. 318, there are only 2 instances of substitution, out of which only 1 instance represents acase of intersentence cohesion:

$$
\begin{aligned}
& \text { If you file a civil action, you must name as the defendant in the } \\
& \text { complaint the person who is the official agency head or department } \\
& \text { head, identifying that person by his or her full name and official title. } \\
& \text { Failure to do so may result in the dismissal of your case in court (Text } \\
& \text { 2, Ses 29-30). }
\end{aligned}
$$

The lack of more occurences of substitution in the analysed texts may be attributed to the effort to avoid any possible ambiguity or misunderstanding. Therefore in these legal texts, this cohesive device is used only once, in a pair of adjacent sentences, where there is no doubt of what element is being repudiated. Additionally, the type of substitution that is used is verbal substitute for proposition do so, which refers to the the whole proposition of the preceding sentence and thus carries more information than a simple nominal or verbal substitute.

A further reason for avoiding the use of substitution in legal texts may be the fact that this cohesive device generally involves some kind of redefinition of the item. In 
legal texts, reference and reiteration of lexical items are therefore preferred over substitution and ellipsis.

\subsection{Ellipsis}

Halliday and Hasan (1976) define ellipsis as "substitution by zero" or as "something understood without saying". It is a relation between words or groups of words or clauses, i.e. it is a grammatical relation (p. 142). If the missing information can be recovered from the preceding text, ellipsis becomes a means of creating textual cohesion.

In its frequency of occurence in the analysed legal texts, ellipsis does not substantially differ from substitution. In the six analysed legal texts containing 318 sentences, there are only two occurences of ellipsis functioning as an intersentence cohesive device:

The agency asserts that these documents are new and material evidence. These indicate that appellant asserted in her earlier complaint that the incident concerning the theft of her jacket was orchestrated in retaliation for her prior EEO activity (Text 2, Se $12-13$ ).

(6)

$$
\begin{aligned}
& \text { The record also shows that one comparator received a fourteen day } \\
& \text { suspension for a physical assault. The disciplinary records were } \\
& \text { unavailable for the remaining seven (Text } 4 \text {, Se 19). }
\end{aligned}
$$

In both cases, ellipsis does not decrease precision or unambiguity of expression. Not only does it occur in a sentence following the sentence with a full, non-elliptical construction, it also contains specific expressions (a specific deictic and a cardinal numeral). In both cases, the cohesive relation between the elliptical and non elliptical nominal group is clear at the first sight and it is easy to see which head of the nominal group is repudiated.

The first case (these documents - these) can be also regarded as a combination of a reference item and ellipsis, thus constituting a stronger cohesive tie.

In the analysed texts, there were found examples of elliptical constructions not functioning as intersentence cohesive devices but referring to parts of the text or to previous or following sentences of the text and thus linking different paragraphs of the text : 
(7)

Both the request and the civil action must be filed within the time limits as stated in the paragraph above („Right to File A Civil Action“) (Text 5, Se 44).

(8) For the reasons that follow, we affirm the FAD as modified herein (Text $6, \mathrm{Se} 3)$.

Constructions that are similar to ellipsis and are often repeated in the analysed texts are the so called whiz deletions: work center different than his own...., terms of the agreement relevant to complainant's overtime requirements. Although they are not examples of intersentence ellipsis, they refer to other parts of the text, where the reader has to look for the missing information.

These referential uses of elliptical constructions provide another proof supporting the hypothesis that reference is the most frequent cohesive relation in these types of texts.

\subsection{Conjunction}

While reference, substitution and ellipsis are considered to be means of grammatical cohesion by Halliday and Hasan because they involve closed classes of items or gaps, conjunction is called "a relation on the borderline of grammatical and lexical cohesion" (p. 34). On the one hand, it is a semantic relation and on the other hand, it is expressed by means of a closed set of grammatical resources.

Conjunctive ties, which semantically express logical relations among ideas in the text and therefore are of crucial importance for the very essence of legal writing, represent 88 instances of the total number of cohesive ties (265). The distribution of conjunctive cohesive ties is illustrated in graph 2, showing that the second part of the second hypothesis was disproved: in the analysed corpus, additive conjunctives outnumber causal conjunctives by $5 \%$. The high incidence of additive conjunctives in the analysed texts can be possibly explained by the tendency towards enumeration, listed by many linguists (Maley, 1987; Tomášek, 1998; Bhatia, 2004) among the characteristic features of legal writing. 


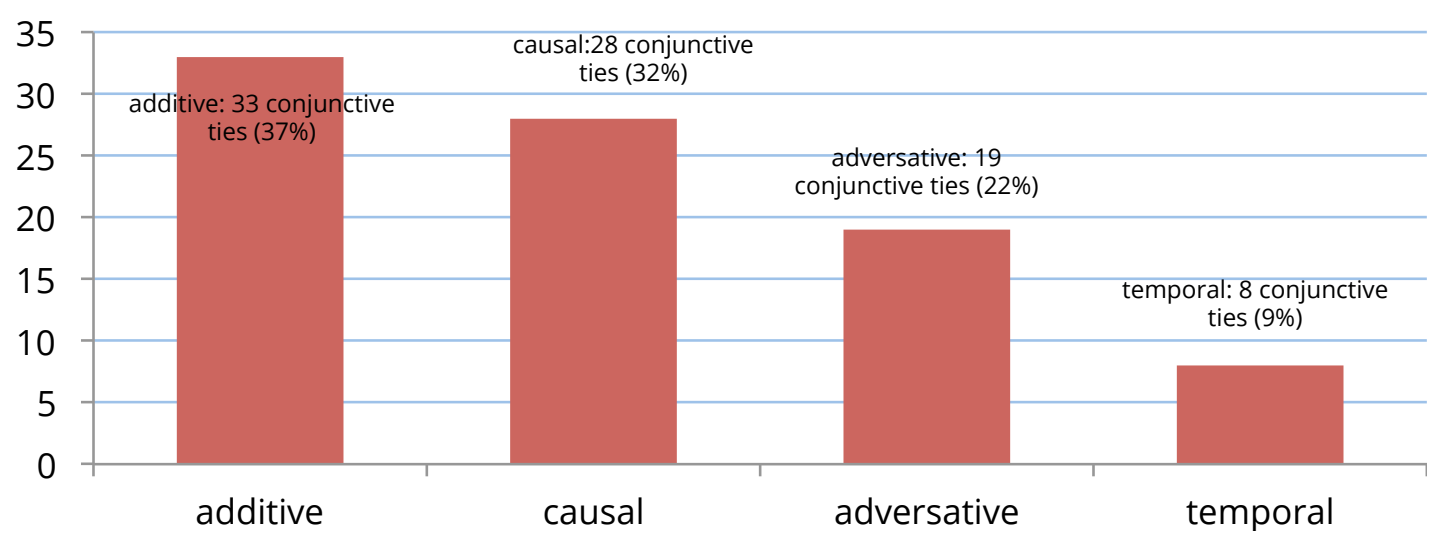

Graph 3. Distribution of conjunctive cohesive ties in the corpus of Appellate Court Decisions

Causal conjunctives are also often used together with referential items, e.g. in such cases, under these circumstances, etc, which increases their linking force because in addition to creating a logical semantic relation between sentences, they also create a referential tie. In such cases, a conjunctive element together with a reference item create two cohesive ties with the previous sentence:

$$
\begin{aligned}
& \text { The FAD concluded that appellant failed to establish a prima facie case } \\
& \text { of sex discrimination because he presented no evidence that similarly } \\
& \text { situated individuals not in his protected class were treated differently } \\
& \text { under similar circumstances. Notwithstanding this determination, the } \\
& \text { FAD further found that the agency articulated a legitimate, } \\
& \text { nondiscriminatory reason for its action which was not shown to be } \\
& \text { pretextual (Text } 4 \text {, Se 13, 14). }
\end{aligned}
$$

The above sentences, representing a typical example of frequent co-occurence of referential and conjunctive cohesive ties in the analysed corpus, are linked cohesively in two different ways. The adversative emphatic conjunctive notwithstanding creates an adversative semantic relation between the two sentences and at the same time, the demonstrative this in the nominal group this determination creates a referential tie with the previous sentence because it refers back to the meaning of the preceding sentence.

The cohesive force of conjunctive items further consists in the fact that they occur cumulatively in one sentence, thus linking this sentence to the previous or following text or both.

Pursuant to the findings and conclusions herein, the agency shall comply with the following order (Text 6, Se 40). 
The above sentence is cohesively linked to the previous text by means of the causal emphatic conjunctive pursuant to and at the same time it also refers to the following text (Order, Se 41).

As in the above sentences, there are many other sentences in which various types of conjunctives are used together in a single sentence, thus creating manifold cohesive links between that sentence and the surrounding text. In addition, there are also sentences in which two conjunctives of the same type are used together, e.g. in the following sentences, including two adversative emphatic conjunctives and one causal conjunctive:

$$
\begin{aligned}
& \text { Therefore, notwithstanding the dispute as to whether S interviewed } \\
& \text { witness co - workers, we find that S and M nonetheless made } \\
& \text { a legitimate credibility determination based on the interviews of } \\
& \text { appellant and FCW, and the two prior incident reports against appellant } \\
& \text { by FCW (Text 4, Se 34). }
\end{aligned}
$$

\section{Comparison of grammatical means of textual cohesion in legal register and other selected registers}

Means of textual cohesion were studied by many linguists in other registers (cohesion in literary texts was studied by Gutwinski, 1975; cohesion in academic texts was studied by Hinkel, 2000; etc.). However, most of these studies are based on extensive corpora of texts, which exhibit a larger variation in the occurence and frequency of cohesive ties than the small-scale research conducted in this study.

A research into textual cohesion, which is approximately of the same extent as research in this paper, was conducted by Janina Buitkiene (2005). Results of her study of textual cohesion in fiction (K. Mansfield's short story The Tiredness of Rosabel) and in newspaper discourse (articles from The Times) can be compared with the results presented in this paper as follows: 


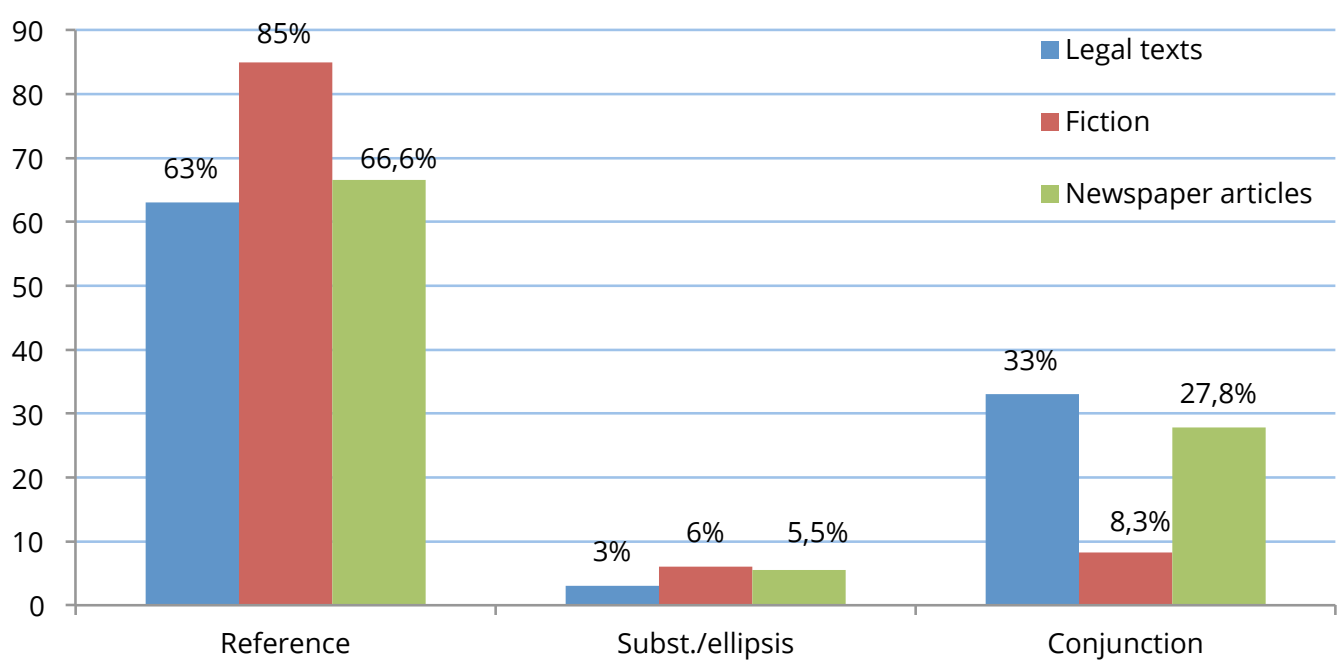

Graph 4. Distribution of grammatical cohesive ties in legal texts, in fiction and in newspaper articles. Data concerning the occurrence of grammatical cohesive ties in fiction and newspaper articles were adopted from Buitkiene (2005). Buitkiene treats substitution and ellipsis as a single category, therefore the occurences of ellipsis and substitution as cohesive devices in the analysed legal texts were included in a single category as well

The comparison of data revealed that reference is the most frequent grammatical cohesive device in fiction, where its occurence is higher than in legal register by $21 \%$. This can be explained by the fact that pronominal reference and extended reference naturally occur more frequently in less formal registers and their occurence in formal legal register was proved to be extremely rare. As already mentioned above, reiteration of lexical items is the preferred cohesive device in legal register, where it is used instead of pronominal reference for the sake of precision. For the same reason, substitution and ellipsis were avoided in the analysed legal texts and as the graph demonstrates, these cohesive devices are more common in fiction and also in newspaper style. It is also acknowledged by Halliday and Hasan that these two cohesive devices are much more common in conversational styles and in dialogue than in written and formal genres and both registers analysed by Buitkiene definitely involve more conversational elements than legal texts. The comparison also shows that conjunction is much more frequent in legal texts than in both fiction and newspaper articles. This result was anticipated, on the basis of importance of logical organization of content in legal register, which is expressed overtly by conjunctions. On the other hand, the lowest occurence of conjunction in fiction in comparison with other genres can be justified by the research presented by Leech et al. in Style in Fiction (2007): "We suggest that in the history of fiction writing, there has been a progressive tendency, over the past three hundred years, to dispense with such logical connections between sentences, and to rely instead upon inferred 
connections." (p. 201). The authors further claims that an abundant usage of conjunctives creates logically articulated discourse but leaves little to the reader's imagination, which fully explains the high employment of intersentence connectors in legal register and their extremely low occurence in fiction.

\section{Conclusion}

The results of the analysis of grammatical means of textual cohesion show that the most prevailing cohesive device used in the analysed texts is reference, which represents 164 out of all the 265 cohesive ties. Reference also represents the most versatile group of cohesive ties which fulfill various functions within the text : demonstrative referential ties, apart from being the most numerous group (amounting to 117 instances) also have the greatest cohesive force. They link adjacent sentences and they also create referential links between paragraphs. Comparative referential ties link remote sentences and often link very precise and detailed data, thus contributing to precision of the legal register. In general, reference can be seen not only as the most frequent intersentence cohesive device, but also as the most prevailing general tendency in the analysed texts: there are a lot of constructions in the text which do not contain intersentence referential cohesive items but are referential in nature, i.e. the reader has to refer to other part of the text for the interpretation of their meaning (e.g. some elliptical constructions as stated above, as charged in the former notice of removal, as modified herein, etc.). Referential ties also often function in association with conjunctive relations. Thus in the interplay of cohesive relations within the texts, reference is definitely the most dominant relation, which holds the text together as a single unit. On the other hand, substitution and ellipsis are very scarce intersentence cohesive devices. This can be accounted for by the requirement of precision and formality of the legal register.

Both expectations concerning the number and types of cohesive ties that are necessary for intelligibility of the text were confirmed: the average number of ties per sentence is 1.52 and the most prevailing types of cohesive ties were proved to be immediate ties (197 out of 256 instances).

The hypothesis concerning the distribution of types of cohesive ties was proved only partially: On the one hand, the most frequent type of grammatical cohesive ties are reference and conjunction as expected, more specifically demonstrative reference (117 cohesive ties) and additive conjunction (33 cohesive ties). The original expectation was that the most frequent types would be demonstrative reference and causal conjunction. The analysis also revealed an interesting fact, concerning conjunctive ties: they frequently form double cohesive ties, which are both 
referential and conjunctive and their cohesive force also lies in the fact that they often occur cumulatively.

To summarize the findings of the analysis, it can be said that the analysed legal genre contains a great deal of evidence in support of the hypothesis about the most dominant semantic type of cohesive ties (demonstrative reference really represents the most frequent type of referential relations as it was hypothesized) but on the other hand, there is also a great deal of evidence against the hypothesis concerning the anticipated occurence of conjunctive ties (i.e. additive conjunctives were proved to be the most frequent type). All the demonstrative referential ties are unambiguous and clear for interpretation.

In the comparison of the individual types of grammatical cohesive ties with their occurence in fiction and newspaper articles it transpired that reference is the most dominant cohesive relation in all the registers under comparison. On the other hand, conjunction, i.e. the second most frequent cohesive type in legal register, is typical of this register while in fiction and in newspaper style its occurence is significantly lower.

\section{About the author}

Zuzana Nadova is currently a PhD student enrolled in the doctoral programme in "British and American Studies" at Pavol Jozef Šafárik University in Košice, Slovakia where she teaches Business English, Terminology of International Economic Relations and Translation, and Legal English. At the same time, she is also enrolled in the PhD programme in "Linguistics" at Utrecht University in Utrecht, the Netherlands. In 2011, she successfully defended her master thesis entitled "Distribution of Non-finite Clauses in Acts of Parliament vs. Appellate Judgments". She is the author of the article "Distribution of Semi-clause Constructions in Acts of Parliament vs. Appellate Judgments" published in Comparative Legilinguistics. International Journal for Legal Communication,18(2014), pp. 9-25.

\section{Article history}

Paper received: $5^{\text {th }}$ December 2014

Paper received in revised form and accepted for publication: $8^{\text {th }}$ June 2015 


\section{References}

Primary sources: Analysed Appellate Court Decisions

Text 1: http://www.eeoc.gov/decisions/01994009.txt

Text 2: http://www.eeoc.gov/decisions/05970477.txt

Text 3: http://www.eeoc.gov/decisions/03980097.txt

Text 4: http://www.eeoc.gov/decisions/01971521.txt

Text 5: http://www.eeoc.gov/decisions/01A03228.txt

Text 6: http://www.eeoc.gov/decisions/04a00009.r.txt

\section{Secondary sources}

Bajzíková, E. (1995). Slovenský jazyk. Textová syntax. Bratislava: Stimul.

Bhatia, V. K. et al. (2004). Legal discourse. Opportunities and threats for corpus linguistics. In T. Upton et al. (Eds.). Discourse in the professions. Perspectives from corpus linguistics (203234). Amsterdam: John Benjamins Publishing Company.

Bolinger, D. (1975). Aspects of language. New York: Harcourt Brace Jovanovich.

Buitkiene, J. (2005). Variability of cohesive devices across registers. Studies about languages, 7, 59-68.

Danet, B. Legal discourse. (1985). In T.A. van Dijk (Ed.). Handbook of discourse analysis, Vol. 1, Disciplines of discourse (273 - 389). London: Academic Press Inc.

Engberg, J. \& Heller, D. (2008). Vagueness and indeterminacy in law. In K. Vijay et al. (eds.) Legal discourse across cultures and systems (145-168). Hong Kong: Hong Kong University Press.

Gutwinski, W. (1976). Cohesion in literary texts. A study of some grammatical and lexical features of English discourse. The Hague: Mouton, Janua Linguarum Series Minor.

Gibbons, J. (2007). The language and the law. In A. Davies \& C. Elder (eds.) The handbook of applied linguistics (258-303). Malden, MASS: Wiley - Blackwell Publishing.

Halliday, M.A.K. \& Hasan, R. (1976). Cohesion in English. London : Longman.

Hinkel, E. (2001) . Matters of cohesion in L2 academic texts. Applied Language Learning 2, 111 132. 
Kurzon, D. (1983). Research in text connexity and text coherence: A survey. In H. Buske (ed.) Papiere Zur Textlinguistik, Vol. 2 (369 - 378)

Laster, K. (2001). Language and law. In K. Laster Law as culture, 2nd ed. (243 - 267). Annandale, VA: The Federation Press.

Leech, G. et al. (2007). Style in fiction. A linguistic introduction to English fictional prose (2nd ed.). London: Longman.

Maley, Y. (1987). The language of legislation. Langage in society, 16 (1), 25 - 48.

Mellinkoff, D. (1963). Language of the law. Boston: Little, Brown and Co.

Scott, M. \& Thompson, G. (2001). Patterns of text. In honour of Michael Hoey. Amsterdam: John Benjamins Publishing Company.

Štekauer, P. (1995). An encyclopaedia of english linguistics. Prešov: Slovacontact.

Taboada, M. T. (2004). Building coherence and cohesion. Amsterdam: John Benjamins Publishing Company.

Tanskannen, S. K. (2006). Collaborating towards coherence. Amsterdam: John Benjamins Publishing Company.

Tomášek, T. (1998). Překlad v právní praxi. Praha: Linde.

Trosborg, A. (2000). Analyzing professional genres. Amsterdam: John Benjamins Publishing Company.

\section{Appendix 1}

Text 1 - Analysis of Grammatical Means of Textual Cohesion

\begin{tabular}{l|l|l|l|l|l}
\hline Se. Nr. & $\begin{array}{l}\text { Nr. of } \\
\text { ties }\end{array}$ & Cohesive item & Type & Distance & $\begin{array}{l}\text { Presupposed } \\
\text { item }\end{array}$ \\
\hline 2 & 1 & the (appeal) & R, dem.,def.art. & 0 & an appeal \\
\hline 4 & 2 & $\begin{array}{l}\text { for the following } \\
\text { reasons }\end{array}$ & $\begin{array}{l}\text { C, causal, specific, } \\
\text { I, reason }\end{array}$ & K & following text \\
\cline { 3 - 6 } & $\begin{array}{l}\text { the (agency`s final } \\
\text { decision) }\end{array}$ & R, dem., def. art. & N.2 & $\begin{array}{l}\text { a final agency } \\
\text { decision }\end{array}$ \\
\hline 5 & 1 & the (relevant time) & R, dem., def. art. & N.1 & $\begin{array}{l}\text { November 14, } \\
1994\end{array}$ \\
\hline 6 & 1 & Also & $\begin{array}{l}\text { C, additive, simple, } \\
\text { I }\end{array}$ & 0 & Se 5 \\
\hline
\end{tabular}




\begin{tabular}{|c|c|c|c|c|c|}
\hline 7 & 2 & that (surveillance) & $\begin{array}{l}\mathrm{R} \text {, dem, dem. } \\
\text { pronoun, funct. as } \\
\text { deictic }\end{array}$ & 0 & a surveillance \\
\hline & & $\begin{array}{l}\text { the (agency`s } \\
\text { premises) }\end{array}$ & R, dem., def. art. & N. 1 & $\begin{array}{l}\text { Springfield Post } \\
\text { Office Facility in } \\
\text { Illinois }\end{array}$ \\
\hline 8 & 1 & the (postal inspector) & R, dem., def. art. & 0 & $\begin{array}{l}\text { Postal } \\
\text { Inspector }\end{array}$ \\
\hline \multirow[t]{2}{*}{9} & 2 & the (inspectors) & R, dem., def. art. & M. 1 & $\begin{array}{l}\text { The postal } \\
\text { Inspector } \rightarrow \\
\text { Postal } \\
\text { Inspectors }\end{array}$ \\
\hline & & additional & $\begin{array}{l}\text { R, comp., } \\
\text { difference }\end{array}$ & 0 & Marijuana \\
\hline 10 & 1 & Further & $\begin{array}{l}\text { C, additive, } \\
\text { complex, emphatic, } \\
\text { I }\end{array}$ & 0 & Se 9 \\
\hline 12 & 1 & the (removal notice) & R, dem., def.art. & 0 & $\begin{array}{l}\text { a removal } \\
\text { notice }\end{array}$ \\
\hline 13 & 1 & Further & $\begin{array}{l}\text { C, additive, } \\
\text { complex, emphatic, } \\
\text { I }\end{array}$ & N. 2 & Se 10 \\
\hline 15 & 1 & the (act) & R, dem., def.art. & N. 7 & $\begin{array}{l}\text { possession and } \\
\text { use of } \\
\text { alcohol and } \\
\text { marijuana }\end{array}$ \\
\hline 16 & 1 & Also & C, additive, simple, I & 0 & Se 15 \\
\hline 18 & 1 & subsequently & $\begin{array}{l}\text { C, temporal, } \\
\text { simple, sequential, } \\
\text { E }\end{array}$ & N. 3 & Se 14 \\
\hline 20 & 1 & $\begin{array}{l}\text { the (drug and } \\
\text { alcohol program) }\end{array}$ & R, dem., def.art. & N. 1 & $\begin{array}{l}\text { a drug and } \\
\text { alcohol } \\
\text { program }\end{array}$ \\
\hline 21 & 1 & the (removal notice) & R, dem., def. art. & N. 8 & $\begin{array}{l}\text { the removal } \\
\text { notice }\end{array}$ \\
\hline 24 & 1 & $\begin{array}{l}\text { at the conclusion of } \\
\text { the investigation }\end{array}$ & $\begin{array}{l}\text { C, temporal, } \\
\text { conclusive, E }\end{array}$ & 0 & Se 23 \\
\hline 29 & 3 & specifically & C, additive, & 0 & Se 28 \\
\hline
\end{tabular}




\begin{tabular}{|c|c|c|c|c|c|}
\hline & & & $\begin{array}{l}\text { apposition, } \\
\text { expository, I }\end{array}$ & & \\
\hline & & alleged (disability) & R, dem., def. art. & $\mathrm{N} .26$ & $\begin{array}{l}\text { disability (drug } \\
\text { addiction) }\end{array}$ \\
\hline & & the (FAD) & R, dem., def. art. & $\begin{array}{l}\text { N. } 1 \\
\text { M. } 1\end{array}$ & $\begin{array}{l}\rightarrow \text { its FAD } \rightarrow \\
\text { a final decision }\end{array}$ \\
\hline \multirow[t]{2}{*}{30} & \multirow[t]{2}{*}{2} & Rather & $\begin{array}{l}\text { C, adversative, } \\
\text { correction of } \\
\text { meaning, I }\end{array}$ & 0 & Se 29 \\
\hline & & he $(2 x)$ & $\begin{array}{l}\text { R, pronominal, } \\
\text { sing., masc. }\end{array}$ & 0 & Complainant \\
\hline 31 & 1 & Also & C, additive, simple, I & 0 & Se 30 \\
\hline \multirow[t]{2}{*}{32} & 2 & Further & $\begin{array}{l}\text { C, additive, } \\
\text { complex, emphatic, } \\
\text { I }\end{array}$ & 0 & Se 31 \\
\hline & & the ( FAD) & R, dem., def. art. & N. 2 & the FAD \\
\hline 37 & 1 & in such cases & $\begin{array}{l}\text { C, causal, } \\
\text { conditional } \\
\text { relation, emphatic, } \\
\text { I }\end{array}$ & 0 & Ses 35,36 \\
\hline 40 & 1 & $\begin{array}{l}\text { under these } \\
\text { circumstances }\end{array}$ & $\begin{array}{l}\text { C, causal, } \\
\text { conditional, } \\
\text { generalized, I }\end{array}$ & & preceding text \\
\hline \multirow[t]{3}{*}{41} & \multirow[t]{3}{*}{3} & more favourably & $\begin{array}{l}\text { R, comp., } \\
\text { difference, } \\
\text { comparison of } \\
\text { quality, funct. as } \\
\text { adjunct }\end{array}$ & N. 11 & Ses 29,30 \\
\hline & & $\begin{array}{l}\text { different (postal } \\
\text { facility) }\end{array}$ & $\begin{array}{l}\text { R, comp., } \\
\text { difference, funct. as } \\
\text { epithet }\end{array}$ & N. 36 & $\begin{array}{l}\text { Springfield Post } \\
\text { Office Facility }\end{array}$ \\
\hline & & $\begin{array}{l}\text { different } \\
\text { (supervisors) }\end{array}$ & $\begin{array}{l}\text { R, comp, } \\
\text { difference, funct. as } \\
\text { epithet }\end{array}$ & N. 29 & $\mathrm{M} 1, \mathrm{M} 2$ \\
\hline \multirow[t]{2}{*}{42} & 2 & accordingly & C, causal, general, I & 0 & Se 41 \\
\hline & & We & $\begin{array}{l}\text { R, pronominal, } \\
\text { pers. pronoun, } \\
\text { plural }\end{array}$ & 0 & $\begin{array}{l}\text { The } \\
\text { Commission }\end{array}$ \\
\hline
\end{tabular}




\begin{tabular}{|c|c|c|c|c|c|}
\hline \multirow[t]{5}{*}{43} & 3 & Further & $\begin{array}{l}\text { C, additive, } \\
\text { complex, } \\
\text { emphatic, I }\end{array}$ & 0 & Se 42 \\
\hline & & We & $\begin{array}{l}\text { R, pronominal, } \\
\text { pers. pronoun. } \\
\text { Plural }\end{array}$ & M. 1 & $\begin{array}{l}\rightarrow \text { we } \rightarrow \text { the } \\
\text { Commission }\end{array}$ \\
\hline & & the (agency`s action) & R, dem., def. art. & $\begin{array}{l}\text { N. } 39 \\
\text { M. } 1\end{array}$ & $\begin{array}{l}\rightarrow \text { its action } \rightarrow \\
\text { he was issued } \\
\text { a notice of } \\
\text { removal }\end{array}$ \\
\hline & & $\begin{array}{l}\text { the (position in } \\
\text { question) }\end{array}$ & R, dem., def. art. & N. 39 & $\begin{array}{l}\text { A PS - } 04 \text { mail } \\
\text { handler }\end{array}$ \\
\hline & & We & $\begin{array}{l}\text { R, pronominal, } \\
\text { pers. pronoun, } \\
\text { plural }\end{array}$ & M. 2 & $\begin{array}{l}\rightarrow \text { we } \rightarrow \text { we } \rightarrow \\
\text { the } \\
\text { Commission }\end{array}$ \\
\hline \multirow[t]{3}{*}{46} & 3 & therefore & $\begin{array}{l}\text { C, causal, general, } \\
\text { simple, I }\end{array}$ & N. 1 & Ses $40-44$ \\
\hline & & $\begin{array}{l}\text { the (agency`s final } \\
\text { decision) }\end{array}$ & R, dem., def. art. & N. 6 & the FAD \\
\hline & & We & $\begin{array}{l}\text { R, pronominal, } \\
\text { pers. pronoun, } \\
\text { plural }\end{array}$ & N. 1, M. 3 & $\begin{array}{l}\rightarrow \text { we } \rightarrow \text { we } \rightarrow \\
\text { we } \rightarrow \text { the } \\
\text { Commission }\end{array}$ \\
\hline 48 & 1 & Or & $\begin{array}{l}\text { C, additive simple, } \\
\text { alternative, I }\end{array}$ & 0 & Se 47 \\
\hline \multirow[t]{2}{*}{52} & 2 & $\begin{array}{l}\text { the (applicable filing } \\
\text { period) }\end{array}$ & R, dem., def. art. & N. 2 & $\begin{array}{l}\text { within } 20 \text { or } 30 \\
\text { calendar days }\end{array}$ \\
\hline & & $\begin{array}{l}\text { the ( request to } \\
\text { reconsider) }\end{array}$ & R, dem., def. art. & 0 & $\begin{array}{l}\text { a written } \\
\text { request }\end{array}$ \\
\hline 54 & 1 & Also & $\begin{array}{l}\text { C, additive, simple, } \\
\text { I, }\end{array}$ & 0 & Se 53 \\
\hline \multirow[t]{2}{*}{55} & 2 & the (time period) & R, dem., def. art. & $\begin{array}{l}\text { M. } 1 \\
\text { N. } 5\end{array}$ & $\begin{array}{l}\rightarrow \text { the } \\
\text { applicable filing } \\
\text { period } \rightarrow 20 \text { or } \\
30 \text { calendar } \\
\text { days }\end{array}$ \\
\hline & & $\begin{array}{l}\text { the (timely filing of } \\
\text { the request) }\end{array}$ & R, dem., def. art. & $\begin{array}{l}\text { M. } 1 \\
\text { N. } 5\end{array}$ & $\begin{array}{l}\rightarrow \text { the } \\
\text { applicable filing }\end{array}$ \\
\hline
\end{tabular}




\begin{tabular}{|c|c|c|c|c|c|}
\hline & & & & & $\begin{array}{l}\text { period } \rightarrow 20 \text { or } \\
30 \text { calendar } \\
\text { days }\end{array}$ \\
\hline 57 & 1 & the ( deadline) & R, dem., def. art. & $\begin{array}{l}\text { M. } 2 \\
\text { N. } 4\end{array}$ & $\begin{array}{l}\rightarrow \text { the } \\
\text { applicable filing } \\
\text { period } \rightarrow \text { the } \\
\text { time period } \rightarrow \\
20 \text { or } 30 \\
\text { calendar days }\end{array}$ \\
\hline 60 & 1 & that ( person) & $\begin{array}{l}\text { R, dem., } \\
\text { dem.pronoun } \\
\text { funct. as deictic }\end{array}$ & 0 & the person \\
\hline 61 & 1 & do so & $\begin{array}{l}\text { S, verbal, verbal } \\
\text { substitute for } \\
\text { proposition }\end{array}$ & 0 & $\begin{array}{l}\text { name as the } \\
\text { defendant... }\end{array}$ \\
\hline 68 & 1 & $\begin{array}{l}\text { the (time limits as } \\
\text { stated in the } \\
\text { paragraph above) }\end{array}$ & R, dem., def. art. & N. 8 & $\begin{array}{l}90 \text { calendar } \\
\text { days }\end{array}$ \\
\hline 69 & 1 & $\begin{array}{l}\text { for timeliness } \\
\text { purposes }\end{array}$ & $\begin{array}{l}\text { C, causal, specific, } \\
\text { reason, E }\end{array}$ & & Ses 59, 68, 69 \\
\hline
\end{tabular}

Text 2 - Analysis of Grammatical Means of Textual Cohesion

\begin{tabular}{|c|c|c|c|c|c|}
\hline Se. Nr. & $\begin{array}{l}\text { Nr. of } \\
\text { ties }\end{array}$ & Cohesive item & Type & Distance & Presupposed item \\
\hline 1 & 1 & hereinafter & $\begin{array}{l}\text { C, temporal, l, here } \\
\text { and now relations, } \\
\text { future } \\
\text { OR: R, exoph., } \\
\text { spatial deictical }\end{array}$ & $\mathrm{K}$ & following text \\
\hline \multirow[t]{2}{*}{3} & \multirow[t]{2}{*}{2} & the (party) & R, dem., def. art. & N. 1 & $\begin{array}{l}\text { Dept. of } \\
\text { Transportation }\end{array}$ \\
\hline & & $\begin{array}{l}\text { the (previous } \\
\text { decision) }\end{array}$ & R, dem., def. art. & 0 & $\begin{array}{l}\text { any previous } \\
\text { Commission } \\
\text { decision }\end{array}$ \\
\hline \multirow[t]{2}{*}{4} & 2 & $\begin{array}{l}\text { for the reasons set } \\
\text { forth herein }\end{array}$ & $\begin{array}{l}\text { C, causal, specific, } \\
\text { reason, I }\end{array}$ & $\mathrm{K}$ & following text \\
\hline & & the (agency`s & R, dem., def. art. & N. 2 & a request to the \\
\hline
\end{tabular}




\begin{tabular}{|c|c|c|c|c|c|}
\hline & & request) & & & EEOC \\
\hline 5 & 1 & however & $\begin{array}{l}\text { C, adversative } \\
\text { proper, emphatic, } \\
\text { E }\end{array}$ & 0 & Se 4 \\
\hline 6 & 1 & $\begin{array}{l}\text { the ( previous } \\
\text { decision) }\end{array}$ & R, dem., def. art. & N. 3 & $\begin{array}{l}\text { the decision in Sheila } \\
\text { L. Duhn v. Federico } \\
\text { Pena }\end{array}$ \\
\hline 7 & 1 & Thereof & $\begin{array}{l}\mathrm{R} \text {, dem., } \\
\text { pronominal adverb }\end{array}$ & 0 & $\begin{array}{l}\text { the theft of her } \\
\text { jacket }\end{array}$ \\
\hline \multirow[t]{2}{*}{8} & 2 & the ( complaint) & R, dem., def. art. & 0 & $\begin{array}{l}\text { Appellant`s April 14, } \\
1996 \text { complaint }\end{array}$ \\
\hline & & $\begin{array}{l}\text { the ( allegedly } \\
\text { retaliatory theft of } \\
\text { the jacket) }\end{array}$ & R, dem., def. art. & 0 & $\begin{array}{l}\text { the theft of her } \\
\text { jacket }\end{array}$ \\
\hline \multirow[t]{2}{*}{9} & 2 & the ( prior complaint) & R, dem., def. art. & 0 & $\begin{array}{l}\text { an April 2, } 1996 \\
\text { formal complaint }\end{array}$ \\
\hline & & $\begin{array}{l}\text { the ( previous } \\
\text { decision) }\end{array}$ & R, dem., def. art. & 0 & $\begin{array}{l}\text { a final agency } \\
\text { decision ( FAD) }\end{array}$ \\
\hline \multirow[t]{2}{*}{10} & 2 & Thereon & $\begin{array}{l}\text { R, dem., } \\
\text { pronominal adverb }\end{array}$ & 0 & $\begin{array}{l}\text { the April } 1996 \\
\text { complaint }\end{array}$ \\
\hline & & $\begin{array}{l}\text { the (April 2, } 1996 \\
\text { formal complaint) }\end{array}$ & R, dem., def. art. & 0 & the prior complaint \\
\hline \multirow[t]{4}{*}{11} & 4 & It & $\begin{array}{l}\text { R, dem., } \\
\text { pronominal, sing. } \\
\text { neuter, funct. as } \\
\text { head }\end{array}$ & 0 & the agency \\
\hline & & Also & $\begin{array}{l}\text { C, additive, simple, } \\
\text { I, }\end{array}$ & 0 & Se 10 \\
\hline & & her & $\begin{array}{l}\mathrm{R}, \text { pronominal, } \\
\text { sing. fem., funct. as } \\
\text { possessive, as } \\
\text { deictic }\end{array}$ & 0 & Appellant \\
\hline & & $\begin{array}{l}\text { the earlier } \\
\text { (complaint) }\end{array}$ & $\begin{array}{l}\text { R, comp., } \\
\text { difference, funct. } \\
\text { as epithet }\end{array}$ & N. 1 & $\begin{array}{l}\text { the April } 14,1996 \\
\text { complaint }\end{array}$ \\
\hline 12 & 1 & these (documents) & $\begin{array}{l}\mathrm{R} \text {, dem., dem. } \\
\text { pronoun, pl., funct. } \\
\text { as deictic }\end{array}$ & 0 & $\begin{array}{l}\text { an investigative } \\
\text { affidavit and request } \\
\text { for an administrative }\end{array}$ \\
\hline
\end{tabular}




\begin{tabular}{|c|c|c|c|c|c|}
\hline & & & & & hearing \\
\hline 13 & 1 & These & $\begin{array}{l}\text { E, nominal, specific } \\
\text { deictic as head }\end{array}$ & 0 & these documents \\
\hline 14 & 1 & that ( complaint) & $\begin{array}{l}\mathrm{R} \text {, dem., dem. } \\
\text { pronoun, sg., } \\
\text { funct. as deictic }\end{array}$ & 0 & her earlier complaint \\
\hline \multirow[t]{2}{*}{15} & 2 & the (documentation) & R, dem., def. art. & M. 3 & $\begin{array}{l}\rightarrow \text { these } \rightarrow \text { these } \\
\text { documents } \rightarrow \text { her } \\
\text { investigative affidavit } \\
\text { for that complaint } \rightarrow \\
\text { an investigative } \\
\text { affidavit and request } \\
\text { for an } \\
\text { administrative } \\
\text { hearing }\end{array}$ \\
\hline & & Now & $\begin{array}{l}\mathrm{R} \text {, dem., funct. as } \\
\text { time adverbial }\end{array}$ & N. 14 & $\begin{array}{l}\text { On February 13, } \\
1997\end{array}$ \\
\hline 16 & 1 & therefore & $\begin{array}{l}\text { C, causal, general, } \\
\text { simple, I }\end{array}$ & 0 & Se 15 \\
\hline \multirow[t]{4}{*}{17} & \multirow[t]{4}{*}{4} & notwithstanding & $\begin{array}{l}\text { C, adversative } \\
\text { proper, emphatic, } \\
\text { E }\end{array}$ & 0 & Se 16 \\
\hline & & however & $\begin{array}{l}\text { C, adversative, } \\
\text { contrastive, } \\
\text { emphatic, E }\end{array}$ & 0 & Se 16 \\
\hline & & $\operatorname{our}(4 x)$ & $\begin{array}{l}\text { R, pronominal, pl., } \\
\text { funct. as } \\
\text { possessive, as } \\
\text { deictic }\end{array}$ & 0 & the Commission \\
\hline & & We & $\begin{array}{l}\text { R, pronominal, pl. } \\
\text { funct. as head }\end{array}$ & 0 & the Commission \\
\hline \multirow[t]{2}{*}{18} & 2 & Our & $\begin{array}{l}\mathrm{R} \text {, pronominal, } \\
\text { possessive } \\
\text { pronoun, plural }\end{array}$ & M. 1 & $\begin{array}{l}\rightarrow \text { we, our } \rightarrow \text { the } \\
\text { Commission }\end{array}$ \\
\hline & & $\begin{array}{l}\text { the ( subject } \\
\text { documentation) }\end{array}$ & R, dem., fef. art. & $\begin{array}{l}\text { M. } 5 \\
\text { N. } 1\end{array}$ & $\begin{array}{l}\rightarrow \text { the } \\
\text { documentation } \\
\text { submitted by the } \\
\text { agency } \rightarrow \text { these } \rightarrow\end{array}$ \\
\hline
\end{tabular}




\begin{tabular}{|c|c|c|c|c|c|}
\hline & & & & & $\begin{array}{l}\text { these documents } \rightarrow \\
\text { her investigative } \\
\text { affidavit for that } \\
\text { complaint } \rightarrow \text { an } \\
\text { investigative affidavit } \\
\text { and request for an } \\
\text { administrative } \\
\text { hearing }\end{array}$ \\
\hline \multirow[t]{2}{*}{19} & 3 & therefore & $\begin{array}{l}\text { C, causal, general, } \\
\text { E, simple }\end{array}$ & 0 & Se 18 \\
\hline & & we, our & $\begin{array}{l}\text { R, pronominal, } \\
\text { pers. pronoun, } \\
\text { plural }\end{array}$ & M. 2 & $\begin{array}{l}\rightarrow \text { our } \rightarrow \text { our }(4 \mathrm{x}), \text { we } \\
\rightarrow \text { the Commission }\end{array}$ \\
\hline 21 & 1 & however & $\begin{array}{l}\text { C, adversative, } \\
\text { contrastive, E } \\
\text { emphatic }\end{array}$ & 0 & Se 20 \\
\hline 27 & 1 & however & $\begin{array}{l}\text { C, adversative } \\
\text { proper, I emphatic }\end{array}$ & 0 & Se 26 \\
\hline \multirow[t]{2}{*}{28} & 2 & $\begin{array}{l}\text { the (applicable time } \\
\text { period) }\end{array}$ & R, dem. def. art. & 0 & 30 days \\
\hline & & the ( jurisdiction) & R, dem., def. art. & N. 2 & $\begin{array}{l}\text { an appropriate } \\
\text { United States district } \\
\text { court }\end{array}$ \\
\hline 29 & 1 & the ( complaint) & R, dem., def. art. & $\begin{array}{l}\text { N. } 2 \\
\text { M. } 1\end{array}$ & $\begin{array}{l}\rightarrow \text { your action } \rightarrow \text { a } \\
\text { civil action }\end{array}$ \\
\hline 30 & 1 & do so & $\begin{array}{l}\text { S, verbal, verbal } \\
\text { substitute for } \\
\text { proposition }\end{array}$ & 0 & $\begin{array}{l}\text { name as the } \\
\text { defendant... }\end{array}$ \\
\hline 36 & 1 & $\begin{array}{l}\text { the (time limits as } \\
\text { stated in the } \\
\text { paragraph above) }\end{array}$ & R, dem., def. art. & $\begin{array}{l}\text { M. } 3 \\
\text { N. } 7\end{array}$ & $\begin{array}{l}\rightarrow \text { the applicable } \\
\text { time period } \rightarrow \\
\text { within } 30 \text { calendar } \\
\text { days } \rightarrow 90 \text { or } 30 \\
\text { days }\end{array}$ \\
\hline \multirow[t]{3}{*}{37} & 4 & however & $\begin{array}{l}\text { C, adversative, } \\
\text { emphatic, E }\end{array}$ & N. 8 & Se 22 \\
\hline & & the alleged failure & R, dem., def. art. & N. 29 & the agency`s failure \\
\hline & & $\begin{array}{l}\text { the (April 2, } 1996 \\
\text { complaint) }\end{array}$ & R, dem., def. art. & N. 29 & $\begin{array}{l}\text { her April 2, } 1996 \\
\text { complaint }\end{array}$ \\
\hline
\end{tabular}




\begin{tabular}{l|l|l|l|l|l}
\hline & the (incident) & R, dem., def. art. & N. 19 & $\begin{array}{l}\text { the theft of her } \\
\text { jacket }\end{array}$ \\
\hline
\end{tabular}

Text 3 - Analysis of Grammatical Means of Textual Cohesion

\begin{tabular}{|c|c|c|c|c|c|}
\hline Se. Nr. & $\begin{array}{l}\text { Nr. of } \\
\text { ties }\end{array}$ & Cohesive item & Type & Distance & Presupposed item \\
\hline 2 & 1 & the ( petition) & R,dem. def. art. & 0 & a petition \\
\hline \multirow[t]{2}{*}{4} & \multirow[t]{2}{*}{2} & the (agency) & R, dem. def. art. & N. 2 & MSPB \\
\hline & & previously & $\begin{array}{l}\text { C, temporal, } \\
\text { simple, E, } \\
\text { preceding }\end{array}$ & 0 & Se 3 \\
\hline \multirow[t]{3}{*}{5} & \multirow[t]{3}{*}{3} & $\mathrm{He}$ & $\begin{array}{l}\text { R, personal, } \\
\text { pronominal, sing. } \\
\text { masc. , funct. as } \\
\text { head }\end{array}$ & 0 & the petitioner \\
\hline & & the (removal) & R, dem., def. art. & 0 & a notice of removal \\
\hline & & $\begin{array}{l}\text { the ( November } 1996 \\
\text { last chance } \\
\text { agreement) }\end{array}$ & R, dem., def. art. & N. 1 & $\begin{array}{l}\text { a November } 1996 \\
\text { last chance } \\
\text { agreement }\end{array}$ \\
\hline \multirow[t]{2}{*}{7} & 2 & It & $\begin{array}{l}\mathrm{R} \text {, pronominal, } \\
\text { sing., neuter, funct. } \\
\text { as head }\end{array}$ & 0 & the agreement \\
\hline & & $\begin{array}{l}\text { the (October } 1996 \\
\text { notice of removal) }\end{array}$ & R, dem., def. art. & N. 1 & the removal \\
\hline \multirow[t]{2}{*}{9} & \multirow[t]{2}{*}{2} & $\mathrm{He}$ & $\begin{array}{l}\mathrm{R} \text {, pronominal, } \\
\text { sing. masc., funct. } \\
\text { as head }\end{array}$ & 0 & the petitioner \\
\hline & & $\begin{array}{l}\text { (incident) as charged } \\
\text { (in the former notice) }\end{array}$ & R, comp., similarity & N. 4 & $\begin{array}{l}\text { failure to maintain } \\
\text { a regular work } \\
\text { Schedule }\end{array}$ \\
\hline \multirow[t]{2}{*}{10} & \multirow[t]{2}{*}{2} & $\begin{array}{l}\text { the aforementioned } \\
\text { agreement }\end{array}$ & R, dem., def. art. & 0 & the agreement \\
\hline & & Such & $\begin{array}{l}\text { R, comp., similarity, } \\
\text { funct. as } \\
\text { determiner }\end{array}$ & 0 & the removal \\
\hline 11 & 1 & thereafter & $\begin{array}{l}\text { C, temporal, } \\
\text { complex, }\end{array}$ & 0 & Se 10 \\
\hline
\end{tabular}




\begin{tabular}{|c|c|c|c|c|c|}
\hline & & & sequential, $\mathrm{E}$ & & \\
\hline \multirow[t]{2}{*}{13} & \multirow[t]{2}{*}{2} & accordingly & $\begin{array}{l}\text { C, causal, general, } \\
\text { emphatic, I }\end{array}$ & 0 & Se 11 \\
\hline & & It & $\begin{array}{l}\mathrm{R}, \text { pronominal, } \\
\text { sing. neuter, funct. } \\
\text { as head }\end{array}$ & 0 & the MSPB \\
\hline 14 & 1 & the ( initial decision) & R, dem., def. art. & 0 & its initial decision \\
\hline 15 & 1 & This & R, dem., extended, & 0 & $\begin{array}{l}\text { other } \\
\text { documentation... (S } \\
\text { 14) }\end{array}$ \\
\hline 19 & 1 & neverthless & $\begin{array}{l}\text { C, adversative } \\
\text { proper, emphatic, } \\
\text { E }\end{array}$ & 0 & Se 18 \\
\hline 20 & 1 & he $(2 x)$ & $\begin{array}{l}\text { R, personal, } \\
\text { pronominal, sg. } \\
\text { masc., funct. as } \\
\text { head }\end{array}$ & 0 & the petitioner \\
\hline \multirow[t]{3}{*}{21} & \multirow[t]{3}{*}{3} & he $(3 x)$ & $\begin{array}{l}\text { R, pers. pronom., } \\
\text { sg. masc., funct. as } \\
\text { head }\end{array}$ & M. 1 & $\begin{array}{l}\rightarrow \text { he }(2 x) \rightarrow \text { the } \\
\text { petitioner }\end{array}$ \\
\hline & & Also & $\begin{array}{l}\text { C, additive, simple, } \\
\text { I }\end{array}$ & 0 & Se 20 \\
\hline & & His & $\begin{array}{l}\mathrm{R}, \text { pronominal, } \\
\text { sing. masc., funct. } \\
\text { as possessive, as } \\
\text { head }\end{array}$ & M. 1 & $\begin{array}{l}\text { he } \rightarrow \text { the } \\
\text { petitioner }\end{array}$ \\
\hline 22 & 1 & $\begin{array}{l}\text { additional (medical } \\
\text { documentation) }\end{array}$ & $\begin{array}{l}\text { R, comp., } \\
\text { difference, funct. } \\
\text { as deictic }\end{array}$ & $\begin{array}{l}\text { N. } 7 \\
\text { M. } 1\end{array}$ & $\begin{array}{l}\rightarrow \text { this } \rightarrow \text { medical } \\
\text { documentation }\end{array}$ \\
\hline 23 & 1 & $\mathrm{He}$ & $\begin{array}{l}\text { R, pronominal, } \\
\text { pers. pronoun, } \\
\text { funct. as head }\end{array}$ & 0 & the petitioner \\
\hline \multirow[t]{2}{*}{24} & \multirow[t]{2}{*}{2} & shortly thereafter & $\begin{array}{l}\text { C, temporal, } \\
\text { complex, } \\
\text { sequential, E }\end{array}$ & N. 4 & Se 19 \\
\hline & & Also & $\begin{array}{l}\text { C, additive, simple, } \\
\text { I }\end{array}$ & N. 4 & Se 19 \\
\hline 25 & 1 & It & R, dem., sg. neutr., & 0 & an appeal \\
\hline
\end{tabular}




\begin{tabular}{|c|c|c|c|c|c|}
\hline & & & funct. as head & & \\
\hline 27 & 1 & It & $\begin{array}{l}\text { R, dem., sg. neutr., } \\
\text { funct. as head }\end{array}$ & 0 & a decision \\
\hline 29 & 1 & Now & $\begin{array}{l}\mathrm{R} \text {, dem., adverbial } \\
\text { demonstrative }\end{array}$ & N. 27 & December 29, 1997 \\
\hline 30 & 1 & however & $\begin{array}{l}\text { C, adversative, } \\
\text { contrastive, I }\end{array}$ & 0 & Se 29 \\
\hline 31 & 1 & Further & $\begin{array}{l}\text { C, additive, } \\
\text { complex, emphatic, } \\
\text { I }\end{array}$ & 0 & Se 30 \\
\hline 33 & 1 & Also & C, additive, simple, & 0 & Se 32 \\
\hline 34 & 1 & accordingly & $\begin{array}{l}\text { C, causal, general, } \\
\text { emphatic, I }\end{array}$ & 0 & Se 33 \\
\hline 38 & 1 & do so & $\begin{array}{l}\text { S, verbal, verbal } \\
\text { substitute for } \\
\text { proposition }\end{array}$ & 0 & $\begin{array}{l}\text { name as the } \\
\text { defendant... }\end{array}$ \\
\hline 44 & 1 & $\begin{array}{l}\text { the ( time limits as } \\
\text { stated in the } \\
\text { paragraph above) }\end{array}$ & R, dem., def. art. & N. 7 & 30 days \\
\hline \multirow[t]{2}{*}{46} & \multirow[t]{2}{*}{2} & however & $\begin{array}{l}\text { C, adversative, } \\
\text { contrastive, } \\
\text { emphatic, E }\end{array}$ & 0 & Se 45 \\
\hline & & Such & $\begin{array}{l}\mathrm{R} \text {, comp, similarity, } \\
\text { funct. as } \\
\text { determiner }\end{array}$ & 0 & $\begin{array}{l}\text { prospective } \\
\text { waivers of EEOC } \\
\text { appeal rights }\end{array}$ \\
\hline
\end{tabular}

Text 4 - Analysis of Grammatical Means of Textual Cohesion

\begin{tabular}{l|l|l|l|l|l}
\hline Se. Nr. & $\begin{array}{l}\text { Nr. of } \\
\text { ties }\end{array}$ & Cohesive item & Type & Distance & $\begin{array}{l}\text { Presupposed } \\
\text { item }\end{array}$ \\
\hline 3 & 1 & the ( appeal) & R, dem., def. art. & 0 & a timely appeal \\
\hline 4 & 2 & $\begin{array}{l}\text { for the reasons that } \\
\text { follow }\end{array}$ & $\begin{array}{l}\text { C, causal, specific, } \\
\text { reason, I }\end{array}$ & K & following text \\
\cline { 2 - 5 } & $\begin{array}{l}\text { the ( agency s } \\
\text { decision) }\end{array}$ & R, dem., def. art. & N. 2 & a FAD \\
\hline 5 & 1 & the (relevant time) & R, dem., def. art. & N. 2 & December 1995 \\
\hline 7 & 1 & the alleged altercation & R, dem, def. art. & 0 & Assault \\
\hline
\end{tabular}




\begin{tabular}{|c|c|c|c|c|c|}
\hline \multirow[t]{2}{*}{9} & \multirow[t]{2}{*}{2} & subsequently & $\begin{array}{l}\text { C, temporal, } \\
\text { simple, } \\
\text { sequential, E }\end{array}$ & 0 & Se 8 \\
\hline & & $\mathrm{He}$ & $\begin{array}{l}\text { R, pronominal, } \\
\text { sg.masc., funct. } \\
\text { as head }\end{array}$ & 0 & Appellant \\
\hline 10 & 1 & $\begin{array}{l}\text { at the conclusion of } \\
\text { the investigation }\end{array}$ & $\begin{array}{l}\text { C, temporal, } \\
\text { conclusive, E }\end{array}$ & 0 & Se 9 \\
\hline 11 & 1 & Therein & $\begin{array}{l}\mathrm{R} \text {, dem.,funct. as } \\
\text { pronominal } \\
\text { adverb }\end{array}$ & 0 & a FAD \\
\hline 12 & 1 & this ( decision) & $\begin{array}{l}\text { R, dem., funct. as } \\
\text { deictic }\end{array}$ & M. 1 & $\begin{array}{l}\rightarrow \text { therein } \rightarrow \\
\text { a FAD }\end{array}$ \\
\hline \multirow[t]{2}{*}{13} & \multirow[t]{2}{*}{2} & (treated) differently & $\begin{array}{l}\text { R, comp., } \\
\text { difference, funct. } \\
\text { as adjunct }\end{array}$ & N. 5 & $\begin{array}{l}\text { he was } \\
\text { suspended and } \\
\text { terminated }\end{array}$ \\
\hline & & $\begin{array}{l}\text { similar } \\
\text { (circumstances) }\end{array}$ & $\begin{array}{l}\text { R, comp., } \\
\text { similarity, funct. } \\
\text { as epithet }\end{array}$ & N. 5 & Ses $5,6,7$ \\
\hline \multirow[t]{3}{*}{14} & \multirow[t]{3}{*}{3} & $\begin{array}{l}\text { Notwithstanding this } \\
\text { determination }\end{array}$ & $\begin{array}{l}\text { C, adversative } \\
\text { proper, emphatic, } \\
\text { I }\end{array}$ & 0 & Se 13 \\
\hline & & this (determination) & $\begin{array}{l}\text { R, dem., } \\
\text { extended }\end{array}$ & 0 & Se 13 \\
\hline & & Further & $\begin{array}{l}\text { C, additive, } \\
\text { complex, } \\
\text { emphatic, I }\end{array}$ & 0 & Se 13 \\
\hline \multirow[t]{3}{*}{17} & \multirow[t]{3}{*}{3} & these (comparators) & $\begin{array}{l}\text { R, dem., funct. as } \\
\text { deictic }\end{array}$ & 0 & $\begin{array}{l}13 \text { comparison } \\
\text { employees }\end{array}$ \\
\hline & & $\begin{array}{l}\text { four of these } \\
\text { comparators }\end{array}$ & $\begin{array}{l}\text { R, comp., } \\
\text { quantity }\end{array}$ & 0 & $\begin{array}{l}13 \text { comparison } \\
\text { employees }\end{array}$ \\
\hline & & the same (discipline) & R, comp., identity & N. 10 & $\begin{array}{l}\text { he was } \\
\text { suspended and } \\
\text { terminated }\end{array}$ \\
\hline 18 & 1 & Also & $\begin{array}{l}\text { C, additive, } \\
\text { simple, I }\end{array}$ & 0 & Se 17 \\
\hline 19 & 1 & Seven & $\begin{array}{l}\text { E, nominal, } \\
\text { cardinal }\end{array}$ & 0 & comparators \\
\hline
\end{tabular}




\begin{tabular}{|c|c|c|c|c|c|}
\hline & & & $\begin{array}{l}\text { numerative as } \\
\text { head }\end{array}$ & & \\
\hline 20 & 1 & however & $\begin{array}{l}\text { C, adversative } \\
\text { proper, emphatic, } \\
\text { I }\end{array}$ & 0 & Se 19 \\
\hline \multirow[t]{5}{*}{21} & \multirow[t]{4}{*}{5} & these (records) & $\begin{array}{l}\text { R, dem., funct. as } \\
\text { deictic }\end{array}$ & N. 1 & $\begin{array}{l}\text { the } \\
\text { interdisciplinary } \\
\text { records }\end{array}$ \\
\hline & & Further & $\begin{array}{l}\text { C, additive, } \\
\text { complex, } \\
\text { emphatic, I }\end{array}$ & 0 & Se 20 \\
\hline & & these (altercations) & $\begin{array}{l}\text { R, dem., funct. as } \\
\text { deictic }\end{array}$ & 0 & $\begin{array}{l}\text { physical } \\
\text { altercations }\end{array}$ \\
\hline & & those (of appellant`s) & $\begin{array}{l}\text { R, dem., funct. as } \\
\text { head, } \\
\text { E, nominal, deictic } \\
\text { as head }\end{array}$ & $\mathrm{K}$ & $\begin{array}{l}\text { Ses } 22,23 \\
\text { Circumstances }\end{array}$ \\
\hline & & We & $\begin{array}{l}\text { R, pronominal, } \\
\text { pers. pronoun, } \\
\text { funct. as head }\end{array}$ & N. 5 & the Commission \\
\hline \multirow[t]{2}{*}{24} & \multirow[t]{2}{*}{2} & Also & $\begin{array}{l}\text { C, additive, } \\
\text { simple, I }\end{array}$ & N. 8 & Se 15 \\
\hline & & $\begin{array}{l}\text { the (agency`s } \\
\text { articulated reasons for } \\
\text { its actions) }\end{array}$ & R, dem., def. art. & N. 14 & Se 13 \\
\hline \multirow[t]{3}{*}{25} & 3 & the (incident) & R, dem., def. art. & N. 1 & Se 23 \\
\hline & & We & $\begin{array}{l}\text { R, pronominal, } \\
\text { pers. pronoun, } \\
\text { funct. as head }\end{array}$ & 0 & $\begin{array}{l}\text { The } \\
\text { Commission }\end{array}$ \\
\hline & & this conclusion & $\begin{array}{l}\text { R, dem., } \\
\text { extended }\end{array}$ & 0 & Se 24 \\
\hline \multirow[t]{2}{*}{29} & 2 & however & $\begin{array}{l}\text { C, adversative, } \\
\text { contrastive, } \\
\text { emphatic, E }\end{array}$ & 0 & Se 28 \\
\hline & & such (circumstances) & $\begin{array}{l}\text { R, comp., } \\
\text { similarity, funct. } \\
\text { as determiner }\end{array}$ & 0 & $\begin{array}{l}\text { the employer`s } \\
\text { explanation is } \\
\text { not credible }\end{array}$ \\
\hline 32 & 1 & the alleged assault & R, dem., def. art. & N. 7 & $\rightarrow$ the incident \\
\hline
\end{tabular}




\begin{tabular}{|c|c|c|c|c|c|}
\hline & & & & M. 1 & $\rightarrow \mathrm{S} 23$ \\
\hline \multirow[t]{4}{*}{33} & 4 & They & $\begin{array}{l}\text { R, pronominal, } \\
\text { pl., funct. as head }\end{array}$ & 0 & $\mathrm{~S}$ and $\mathrm{M}$ \\
\hline & & Further & $\begin{array}{l}\text { C, additive, } \\
\text { complex, } \\
\text { emphatic, I }\end{array}$ & 0 & Se 32 \\
\hline & & this (type of conduct) & $\begin{array}{l}\mathrm{R} \text {, dem., funct. as } \\
\text { deictic }\end{array}$ & 0 & $\begin{array}{l}\text { the alleged } \\
\text { assault }\end{array}$ \\
\hline & & $\begin{array}{l}\text { the ( appellant`s work } \\
\text { area) }\end{array}$ & R, dem., def. art. & N. 27 & $\begin{array}{l}\text { South Suburban } \\
\text { Postal Data } \\
\text { Center }\end{array}$ \\
\hline \multirow[t]{4}{*}{34} & 4 & therefore & $\begin{array}{l}\text { C, causal, general, } \\
\text { simple, I }\end{array}$ & 0 & Se 33 \\
\hline & & $\begin{array}{l}\text { notwithstanding (the } \\
\text { dispute) }\end{array}$ & $\begin{array}{l}\text { C, adversative } \\
\text { proper, I, } \\
\text { emphatic }\end{array}$ & N. 8 & Se 25 \\
\hline & & $\begin{array}{l}\text { the (two prior incident } \\
\text { reports) }\end{array}$ & R, dem., def. art. & $\begin{array}{l}\text { N. } 10 \\
\text { N. } 6\end{array}$ & $\begin{array}{l}\text { the incident } \\
\text { report ( S 23), } \\
\text { a written } \\
\text { statement from } \\
\text { a female co- } \\
\text { worker (S 27) }\end{array}$ \\
\hline & & nonetheless & $\begin{array}{l}\text { C, adversative } \\
\text { proper, emphatic, } \\
\text { I }\end{array}$ & 0 & Se 33 \\
\hline 35 & 1 & furthermore & $\begin{array}{l}\text { C, additive, } \\
\text { complex, } \\
\text { emphatic, I }\end{array}$ & 0 & Se 34 \\
\hline \multirow[t]{2}{*}{36} & 2 & $\begin{array}{l}\text { based on these } \\
\text { findings }\end{array}$ & $\begin{array}{l}\text { C, causal, specific, } \\
\text { reason, I }\end{array}$ & & Ses $32,33,34$ \\
\hline & & we conclude & $\begin{array}{l}\text { C, causal, specific, } \\
\text { result, I }\end{array}$ & & Ses $32,33,34$ \\
\hline 37 & 1 & therefore & $\begin{array}{l}\text { C, causal, general, } \\
\text { simple, I }\end{array}$ & 0 & Se 36 \\
\hline 39 & 1 & Or & $\begin{array}{l}\text { C, additive, } \\
\text { simple } \\
\text { alternative, I }\end{array}$ & 0 & Se 38 \\
\hline 46 & 1 & the ( time period) & R, dem., def. art. & N. 4 & 30 or 20 \\
\hline
\end{tabular}




\begin{tabular}{|c|c|c|c|c|c|}
\hline & & & & & calendar days \\
\hline 47 & 1 & the ( timely filing) & R, dem., def. art. & $\begin{array}{l}\text { N. } 4 \\
\text { M. } 1\end{array}$ & $\begin{array}{l}\rightarrow \text { the time } \\
\text { period } \rightarrow 20 \text { or } \\
30 \text { calendar } \\
\text { days }\end{array}$ \\
\hline 48 & 1 & the (deadline) & R, dem., def. art. & $\begin{array}{l}\text { N. } 4 \\
\text { M. } 2\end{array}$ & $\begin{array}{l}\rightarrow \text { the timely } \\
\text { filing } \rightarrow \text { the time } \\
\text { period } \rightarrow 20 \text { or } \\
30 \text { calendar } \\
\text { days }\end{array}$ \\
\hline 51 & 1 & however & $\begin{array}{l}\text { C, adversative, } \\
\text { contrastive, } \\
\text { emphatic, I }\end{array}$ & 0 & Se 50 \\
\hline 52 & 1 & $\begin{array}{l}\text { the (applicable time } \\
\text { period) }\end{array}$ & R, dem., def. art. & $\begin{array}{l}\text { N. } 8 \\
\text { M. } 2\end{array}$ & $\begin{array}{l}\rightarrow \text { the timely } \\
\text { filing } \rightarrow \text { the time } \\
\text { period } \rightarrow 20 \text { or } \\
30 \text { calendar } \\
\text { days }\end{array}$ \\
\hline 54 & 1 & do so & $\begin{array}{l}\text { S, verbal, verbal } \\
\text { substitute for } \\
\text { proposition }\end{array}$ & 0 & $\begin{array}{l}\text { name as the } \\
\text { defendant... }\end{array}$ \\
\hline 61 & 1 & $\begin{array}{l}\text { the ( time limits as } \\
\text { stated in the } \\
\text { paragraph above) }\end{array}$ & R, dem., def. art. & $\begin{array}{l}\text { N. } 10 \\
\text { N. } 11\end{array}$ & $\begin{array}{l}90 / 30 \text { calendar } \\
\text { days }\end{array}$ \\
\hline
\end{tabular}

Text 5 - Analysis of Grammatical Means of Textual Cohesion

\begin{tabular}{l|l|l|l|l|l}
\hline Se. Nr. & $\begin{array}{l}\text { Nr. of } \\
\text { ties }\end{array}$ & Cohesive item & Type & Distance & $\begin{array}{l}\text { Presupposed } \\
\text { item }\end{array}$ \\
\hline 3 & 1 & $\begin{array}{l}\text { the ( settlement } \\
\text { agreement) }\end{array}$ & R, dem., def. art. & N. 1 & $\begin{array}{l}\text { the June 3, 1999 } \\
\text { settlement } \\
\text { agreement }\end{array}$ \\
\hline 4 & 1 & Thereof & $\begin{array}{l}\text { R, dem., funct. as } \\
\text { pronominal } \\
\text { adverb }\end{array}$ & 0 & this agreement \\
\hline 5 & 1 & Thereof & $\begin{array}{l}\text { R, dem., } \\
\text { pronominal } \\
\text { adverb }\end{array}$ & 0 & $\begin{array}{l}\text { Federal agency } \\
\text { or entity }\end{array}$ \\
\hline
\end{tabular}




\begin{tabular}{|c|c|c|c|c|c|}
\hline \multirow[t]{2}{*}{6} & \multirow[t]{2}{*}{2} & The & R, dem. def. art. & N. 4 & $\begin{array}{l}\text { the June 3, } 1999 \\
\text { settlement } \\
\text { agreement }\end{array}$ \\
\hline & & The & R, dem., def. art. & N. 4 & the agency \\
\hline 7 & 1 & specifically & $\begin{array}{l}\text { C, additive, } \\
\text { appositive } \\
\text { relation, } \\
\text { expository, I }\end{array}$ & 0 & Se 6 \\
\hline 8 & 1 & the (official) & R, dem., def. art. & 0 & $\begin{array}{l}\text { an agency } \\
\text { official }\end{array}$ \\
\hline 12 & 1 & Further & $\begin{array}{l}\text { C, additive, } \\
\text { complex, } \\
\text { emphatic, I }\end{array}$ & N. 1 & Se 10 \\
\hline 16 & 1 & This & $\begin{array}{l}\text { R, dem., dem. } \\
\text { pronoun funct. as } \\
\text { deictic }\end{array}$ & N. 1 & $\begin{array}{l}\text { the Plain } \\
\text { Meaning Rule }\end{array}$ \\
\hline 19 & 2 & Also & $\begin{array}{l}\text { C, additive, } \\
\text { simple, I }\end{array}$ & 0 & Se 18 \\
\hline & & other (work centres) & $\begin{array}{l}\text { R, comp., } \\
\text { difference, }\end{array}$ & & $\begin{array}{l}\text { Dept. of the } \\
\text { Navy }\end{array}$ \\
\hline 20 & 3 & in that regard & $\begin{array}{l}\text { C, causal, specific, } \\
\text { respective, } \\
\text { relations, I }\end{array}$ & 0 & Se 19 \\
\hline & & the ( supervisor) & R, dem., def. art. & N. 13 & a supervisor \\
\hline & & $\begin{array}{l}\text { those (terms of the } \\
\text { agreement) }\end{array}$ & $\begin{array}{l}\mathrm{R} \text {, dem., funct. as } \\
\text { deictic }\end{array}$ & 0 & Ses 18,19 \\
\hline 22 & 1 & We & $\begin{array}{l}\text { R, pronominal, } \\
\text { pers. pronoun, } \\
\text { plural }\end{array}$ & 0 & $\begin{array}{l}\text { The } \\
\text { Commission }\end{array}$ \\
\hline 23 & 1 & $\begin{array}{l}\text { for the reasons set } \\
\text { forth herein }\end{array}$ & $\begin{array}{l}\text { C, causal, specific, } \\
\text { reason, I }\end{array}$ & & preceding text \\
\hline 26 & 1 & Or & $\begin{array}{l}\text { C, additive, } \\
\text { simple, } \\
\text { alternative, E }\end{array}$ & 0 & Se 25 \\
\hline 30 & 1 & $\begin{array}{l}\text { the (applicable filing } \\
\text { period) }\end{array}$ & R, dem., def. art. & N. 2 & $\begin{array}{l}20 \text { or } 30 \\
\text { calendar days }\end{array}$ \\
\hline 31 & 1 & the (request) & R, dem., def. art. & N. 6 & a written \\
\hline
\end{tabular}




\begin{tabular}{|c|c|c|c|c|c|}
\hline & & & & & request \\
\hline 32 & 1 & the (time period) & R, dem., def. art. & $\begin{array}{l}\text { M. } 1 \\
\text { N.4 }\end{array}$ & $\begin{array}{l}\rightarrow \text { the } \\
\text { applicable } \\
\text { filing period } \rightarrow \\
20 \text { - } 30 \text { days }\end{array}$ \\
\hline 34 & 1 & the (deadline) & R, dem., def. art. & N. 6 & $\begin{array}{l}\text { within } 20 \text { or } 30 \\
\text { calendar days }\end{array}$ \\
\hline \multirow[t]{2}{*}{37} & 3 & do so & $\begin{array}{l}\text { S, verbal } \\
\text { substitute for } \\
\text { proposition }\end{array}$ & 0 & $\begin{array}{l}\text { name as the } \\
\text { defendant... }\end{array}$ \\
\hline & & $\begin{array}{l}\text { the ( time limits as } \\
\text { stated in the } \\
\text { paragraph above) }\end{array}$ & $\begin{array}{l}\text { R, dem., def. art. } \\
R(E \text {, operator } \\
\text { ellipsis) }\end{array}$ & N. 8 & $\begin{array}{l}\text { within } 90 \\
\text { calendar days } \\
\text { Ses } 27 \text { - } 33\end{array}$ \\
\hline 45 & 1 & $\begin{array}{l}\text { for timeliness } \\
\text { purposes }\end{array}$ & $\begin{array}{l}\text { C, causal, specific, } \\
\text { purpose, E }\end{array}$ & 0 & Se 44 \\
\hline 47 & 1 & These & $\begin{array}{l}\text { R, dem., funct. as } \\
\text { deictic }\end{array}$ & 0 & $\begin{array}{l}\text { revised } \\
\text { regulations }\end{array}$ \\
\hline \multirow[t]{2}{*}{49} & 2 & consequently & $\begin{array}{l}\text { C, causal, general, } \\
\text { emphatic, E }\end{array}$ & 0 & Se 48 \\
\hline & & $\begin{array}{l}\text { the ( revised } \\
\text { regulations) }\end{array}$ & R, dem., def. art. & M. 1 & $\begin{array}{l}\rightarrow \text { these } \\
\text { regulations } \rightarrow \\
\text { revised } \\
\text { regulations }\end{array}$ \\
\hline 50 & 1 & as amended & $\begin{array}{l}\mathrm{R}(\mathrm{E}, \text { verbal, } \\
\text { operator ellipsis, } \\
\text { total) }\end{array}$ & 0 & $\begin{array}{l}\text { the revised } \\
\text { regulations at } \\
\text { C.F.R. part } 1614\end{array}$ \\
\hline
\end{tabular}

Text 6 - Analysis of Grammatical Means of Textual Cohesion

\begin{tabular}{l|l|l|l|l|l}
\hline Se. Nr. & $\begin{array}{l}\text { Nr. of } \\
\text { ties }\end{array}$ & Cohesive item & Type & Distance & $\begin{array}{l}\text { Presupposed } \\
\text { item }\end{array}$ \\
\hline 2 & 1 & The & R, dem., def. art. & 0 & a timely appeal \\
\hline 3 & 4 & $\begin{array}{l}\text { for the reasons that } \\
\text { follow }\end{array}$ & $\begin{array}{l}\text { C, causal, specific, } \\
\text { reason, I }\end{array}$ & K & following text \\
\cline { 2 - 5 } & the ( FAD) & R, dem., def. art. & N.1 & a FAD \\
\cline { 3 - 6 } & We & $\begin{array}{l}\text { R, pronominal, } \\
\text { pers. pronoun, }\end{array}$ & 0 & the Commission \\
\hline
\end{tabular}




\begin{tabular}{|c|c|c|c|c|c|}
\hline & & & plural & & \\
\hline & & as modified (herein) & $\begin{array}{l}\mathrm{R}(\mathrm{E}, \text { verbal, } \\
\text { operator ellipsis) }\end{array}$ & $\mathrm{K}$ & Se 39 \\
\hline 6 & 1 & $\begin{array}{l}\text { at the conclusion of } \\
\text { the investigation }\end{array}$ & $\begin{array}{l}\text { C, temporal, } \\
\text { sequential, E }\end{array}$ & 0 & Se 5 \\
\hline 7 & 1 & the $(\mathrm{AJ})$ & R, dem., def. art. & 0 & $\begin{array}{l}\text { an EEOC } \\
\text { administrative } \\
\text { judge }\end{array}$ \\
\hline \multirow[t]{2}{*}{8} & \multirow[t]{2}{*}{2} & this (matter) & $\begin{array}{l}\text { R, dem., funct. as } \\
\text { deictic }\end{array}$ & N. 2 & Se 5 \\
\hline & & $\begin{array}{l}\text { the (AJ`s } \\
\text { determination) }\end{array}$ & R, dem.,def. art. & 0 & $\begin{array}{l}\text { discrimination } \\
\text { on the basis of } \\
\text { sex }\end{array}$ \\
\hline \multirow[t]{3}{*}{9} & \multirow[t]{3}{*}{3} & this (determination) & $\begin{array}{l}\text { R, dem., funct. as } \\
\text { deictic }\end{array}$ & 0 & $\begin{array}{l}\text { the } \mathrm{AJ} ` \mathrm{~s} \\
\text { determination }\end{array}$ \\
\hline & & the (FAD) & R, dem., def. art. & 0 & $\begin{array}{l}\text { February 28, } \\
1993 \text { FAD }\end{array}$ \\
\hline & & $\begin{array}{l}\text { the (AJ`s finding of } \\
\text { discrimination) }\end{array}$ & R, dem., def. art. & N. 1 & $\begin{array}{l}\text { a recommende } \\
d \text { decision } \\
\text { finding } \\
\text { discrimination } \\
\text { on the basis of } \\
\text { sex }\end{array}$ \\
\hline 10 & 1 & Thereto & $\begin{array}{l}\text { R, dem., } \\
\text { pronominal } \\
\text { adverb }\end{array}$ & S 10 & $\begin{array}{l}\text { retroactive } \\
\text { promotion }\end{array}$ \\
\hline \multirow[t]{2}{*}{13} & \multirow[t]{2}{*}{2} & this (determination) & $\begin{array}{l}\text { R, dem., funct. as } \\
\text { deictic }\end{array}$ & 0 & Se 12 \\
\hline & & additional (10.3 hours) & $\begin{array}{l}\text { R, comp., } \\
\text { difference, funct. } \\
\text { as epithet }\end{array}$ & 0 & $\begin{array}{l}\text { only } 61.65 \\
\text { hours }\end{array}$ \\
\hline 18 & 1 & however & $\begin{array}{l}\text { C, adversative } \\
\text { proper, emphatic, } \\
\text { E }\end{array}$ & 0 & Se 17 \\
\hline 20 & 1 & Further & $\begin{array}{l}\text { C, additive, } \\
\text { complex, } \\
\text { emphatic, I }\end{array}$ & 0 & Se 19 \\
\hline 23 & 1 & Rather & C, adversative, & 0 & Se 22 \\
\hline
\end{tabular}




\begin{tabular}{|c|c|c|c|c|c|}
\hline & & & $\begin{array}{l}\text { corrective, } \\
\text { specific, I }\end{array}$ & & \\
\hline \multirow[t]{3}{*}{26} & 3 & $\begin{array}{l}\text { taking into account } \\
\text { the above } \\
\text { considerarions }\end{array}$ & $\begin{array}{l}\text { C, causal, specific, } \\
\text { result, I }\end{array}$ & & preceding text \\
\hline & & $\begin{array}{l}\text { the ( hours claimed by } \\
\text { apellant`s counsel) }\end{array}$ & R, dem., def. art. & N. 15 & $\begin{array}{l}91.90 \text { hours of } \\
\text { work }\end{array}$ \\
\hline & & we $(2 x)$ & $\begin{array}{l}\text { R, pronominal, } \\
\text { pers. pronoun,pl. }\end{array}$ & N. 16 & $\begin{array}{l}\text { this } \\
\text { Commission }\end{array}$ \\
\hline 27 & 1 & we $(2 x)$ & $\begin{array}{l}\text { R, pronominal, } \\
\text { pers. pronoun, pl. }\end{array}$ & $\begin{array}{l}\text { M. } 1 \\
\text { N. } 16\end{array}$ & $\begin{array}{l}\rightarrow \text { we } \rightarrow \text { this } \\
\text { Commission }\end{array}$ \\
\hline \multirow[t]{3}{*}{28} & 3 & furthermore & $\begin{array}{l}\text { C, additive, } \\
\text { complex, } \\
\text { emphatic, I }\end{array}$ & & Se 27 \\
\hline & & likewise & $\begin{array}{l}\text { C, additive, } \\
\text { comparative } \\
\text { relations, similar, } \\
\text { I }\end{array}$ & 0 & Ses 27 \\
\hline & & We & $\begin{array}{l}\text { R, pronominal, } \\
\text { pers. pronoun, pl. }\end{array}$ & $\begin{array}{l}\text { M. } 2 \\
\text { N. } 16\end{array}$ & $\begin{array}{l}\rightarrow \text { we } \rightarrow \text { we } \rightarrow \\
\text { this } \\
\text { Commission }\end{array}$ \\
\hline \multirow[t]{2}{*}{29} & 2 & accordingly & $\begin{array}{l}\text { C, causal, general, } \\
\text { emphatic, I }\end{array}$ & 0 & Ses 27, 28 \\
\hline & & We & $\begin{array}{l}\text { R, pronominal, } \\
\text { pers. pronoun, pl. }\end{array}$ & $\begin{array}{l}\text { M. } 3 \\
\text { N } 16\end{array}$ & $\begin{array}{l}\text { this } \\
\text { Commission }\end{array}$ \\
\hline \multirow[t]{2}{*}{30} & 2 & $\begin{array}{l}\text { with respect to an } \\
\text { hourly rate of } \\
\text { compensation }\end{array}$ & $\begin{array}{l}\text { C, causal, } \\
\text { respective } \\
\text { relations, I }\end{array}$ & N.18 & Ses 11,12 \\
\hline & & We & $\begin{array}{l}\text { R, pronominal, } \\
\text { pers. pronoun, pl. }\end{array}$ & $\begin{array}{l}\text { M. } 4 \\
\text { N. } 16 \\
\end{array}$ & $\begin{array}{l}\text { this } \\
\text { Commission }\end{array}$ \\
\hline \multirow[t]{2}{*}{34} & 2 & however & $\begin{array}{l}\text { C, adversative, } \\
\text { proper, I }\end{array}$ & 0 & Se 33 \\
\hline & & the (program) & R, dem., def. art. & 0 & $\begin{array}{l}\text { a legal services } \\
\text { program }\end{array}$ \\
\hline \multirow[t]{2}{*}{35} & 2 & moreover & $\begin{array}{l}\text { C, additive, } \\
\text { complex, } \\
\text { emphatic, I }\end{array}$ & 0 & Se 30 \\
\hline & & We & $\mathrm{R}$, pronominal, & M. 5 & this \\
\hline
\end{tabular}




\begin{tabular}{|c|c|c|c|c|c|}
\hline & & & pers. pronoun, pl. & N. 20 & Commission \\
\hline \multirow[t]{3}{*}{37} & 3 & furthermore & $\begin{array}{l}\text { C, additive, } \\
\text { complex, } \\
\text { emphatic, I }\end{array}$ & 0 & Se 36 \\
\hline & & $\begin{array}{l}\text { the (recitation of his } \\
\text { experience) }\end{array}$ & R, dem., def. art. & N. 3 & $\begin{array}{l}\text { he participates } \\
\text { in a legal } \\
\text { services } \\
\text { program } \\
\text { through AFL - } \\
\mathrm{ClO}\end{array}$ \\
\hline & & We & $\begin{array}{l}\text { R, pronominal, } \\
\text { pers. pronoun, pl. }\end{array}$ & $\begin{array}{l}\text { M. } 6 \\
\text { N. } 20\end{array}$ & $\begin{array}{l}\text { this } \\
\text { Commission }\end{array}$ \\
\hline \multirow[t]{4}{*}{38} & 4 & therefore & $\begin{array}{l}\text { C, causal general, } \\
\text { E, simple }\end{array}$ & & previous text \\
\hline & & based on these facts & $\begin{array}{l}\text { C, causal, specific, } \\
\text { I, result }\end{array}$ & & previous text \\
\hline & & we conclude & $\begin{array}{l}\text { C, temporal, I, } \\
\text { conclusive }\end{array}$ & & previous text \\
\hline & & We & $\begin{array}{l}\text { R, pronominal, } \\
\text { pers. pronoun, pl. }\end{array}$ & $\begin{array}{l}\text { M. } 7 \\
\text { N. } 20\end{array}$ & $\begin{array}{l}\text { this } \\
\text { Commission }\end{array}$ \\
\hline \multirow[t]{2}{*}{39} & 2 & accordingly & $\begin{array}{l}\text { C, causal, } \\
\text { general, emphati } \\
\text { C, I }\end{array}$ & 0 & Se 38 \\
\hline & & We & $\begin{array}{l}\text { R, pronominal, } \\
\text { pers. pronoun, pl. }\end{array}$ & $\begin{array}{l}\text { M. } 8 \\
\text { N. } 20\end{array}$ & $\begin{array}{l}\text { this } \\
\text { Commission }\end{array}$ \\
\hline \multirow[t]{2}{*}{40} & 2 & $\begin{array}{l}\text { pursuant to the } \\
\text { findings and } \\
\text { conclusions herein }\end{array}$ & $\begin{array}{l}\text { C, causal, specific, } \\
\text { l, emphatic }\end{array}$ & & previous text \\
\hline & & the following order & R, dem., def. art. & 0 & Order \\
\hline 42 & 1 & as provided below & $\begin{array}{l}\mathrm{R}(\mathrm{E}, \text { verbal, } \\
\text { operator ellipsis) }\end{array}$ & 0 & $\begin{array}{l}\text { implementation } \\
\text { of the } \\
\text { commission`s } \\
\text { decision }\end{array}$ \\
\hline 45 & 1 & the ( report) & R, dem., def. art. & 0 & $\begin{array}{l}\text { its compliance } \\
\text { report }\end{array}$ \\
\hline 49 & 1 & alternatively & $\begin{array}{l}\text { C, additive, } \\
\text { complex, } \\
\text { emphatic, }\end{array}$ & 0 & Se 48 \\
\hline
\end{tabular}




\begin{tabular}{l|l|l|l|l|l}
\hline & & & alternative, I & & \\
\hline
\end{tabular}

List of abbreviations and symbols used in the analysis:

Se -sentence, Ses - sentences

Nr. of ties - number of ties

Type of cohesion :

$\mathrm{R}$ - reference

$\mathrm{R}$, dem. - demonstrative reference

$\mathrm{R}$,pers. - personal reference

$\mathrm{R}$, comp. - comparative reference

def. art. - definite article

C - conjunction : I - internal, E - external

E - ellipsis

S - substitution

Se - sentence

Ses - sentences

Distance:

0 - immediate tie, anaphoric

$\mathrm{K}$ - cataphoric

$\mathrm{N}$ - remote, non - immediate tie

$\mathrm{M}$ - mediated tie

N.number - number of intervening sentenes, which separate the presupposing from the presupposed item while themselves not participating in the presupposition M.number - number of intermediate sentences, which participate in the chain of cohesion, having in them an item which is both presupposed and presupposing. 